

\title{
Eastern Pacific Emitted Aerosol Cloud Experiment (E-PEACE)
}

\author{
Greg Roberts, Lynn Russell, Armin Sorooshian, John Seinfeld, Bruce \\ Albrecht, Athanasios Nenes, Lars Ahlm, Yi-Chun Chen, Matthew Coggon, Jill \\ Craven, et al.
}

\section{To cite this version:}

Greg Roberts, Lynn Russell, Armin Sorooshian, John Seinfeld, Bruce Albrecht, et al.. Eastern Pacific Emitted Aerosol Cloud Experiment (E-PEACE). Bulletin of the American Meteorological Society, 2012, pp.130109100058001. 10.1175/BAMS-D-12-00015 . hal-03554561

\section{HAL Id: hal-03554561 \\ https://cnrs.hal.science/hal-03554561}

Submitted on 4 Feb 2022

HAL is a multi-disciplinary open access archive for the deposit and dissemination of scientific research documents, whether they are published or not. The documents may come from teaching and research institutions in France or abroad, or from public or private research centers.
L'archive ouverte pluridisciplinaire HAL, est destinée au dépôt et à la diffusion de documents scientifiques de niveau recherche, publiés ou non, émanant des établissements d'enseignement et de recherche français ou étrangers, des laboratoires publics ou privés.

\section{(c) (1) $\$$}

Distributed under a Creative Commons Attribution - NonCommerciall 4.0 International 


\section{EASTERN PACIFIC EMITTED AEROSOL CLOUD EXPERIMENT}

by Lynn M. Russell, Armin Sorooshian, John H. Seinfeld, Bruce A. Albrecht, Athanasios Nenes, lars Ahlm, Yi-Chun Chen, Matthew Coggon, Jill S. Craven, Richard C. Flagan, Amanda A. Frossard, Haflidi Jonsson, Eunsil Jung, Jack J. Lin, Andrew R. Metcalf, Robin Modini, Johannes Mülmenstädt, Greg C. Roberts, Taylor Shingler, Siwon SONG, Zhen Wang, and AnNa Wonaschütz

\section{E-PEACE analyzed aircraft and satellite measurements to separate the aerosol cloud effects of three synthetic particle sources from dynamical variability.}

G aps in our fundamental understanding of cloud processes are the central underlying cause of uncertainty in aerosol radiative forcing, even in widespread and well-defined systems such as those for marine stratocumulus cloud formation. Atmospheric aerosol levels have increased markedly since the Industrial Revolution. We do not fully understand the extent to which this increase has affected the cycles of radiant energy and water in the climate system. It has been well established that clouds forming in a polluted environment tend to have more numerous, smaller droplets, which may lead to a cloud of higher cloud optical depth and albedo. Once cloud droplet size and number concentration are perturbed, the dynamics of both the cloud itself and the atmospheric layer in which it is embedded change in a nonlinear manner. Many important questions arise: What is the relationship between cloud microstructure and the aerosol on which the cloud forms? How can the understanding of cloud responses
AfFiliations: Russell, Ahlm, Frossard, Modini, AND MÜLMENSTÄDT-Scripps Institution of Oceanography, University of California, San Diego, La Jolla, California; SOROOSHIAN-Department of Chemical and Environmental Engineering, and Department of Atmospheric Sciences, University of Arizona, Tucson, Arizona; Seinfeld, Chen, Coggon, Craven, Flagan, and Metcalf*_California Institute of Technology, Pasadena, California; ALBRECHT, JuNG, AND SONG-Rosenstiel School of Marine and Atmospheric Sciences, University of Miami, Miami, Florida; NenEs - School of Earth and Atmospheric Sciences, and School of Chemical and Biomolecular Engineering, Georgia Institute of Technology, Atlanta, Georgia; LIN-School of Earth and Atmospheric Sciences, Georgia Institute of Technology, Atlanta, Georgia; Jonsson-Center for Interdisciplinary Remotely-Piloted Aerosol Studies, Marina, California; RoBerTsScripps Institution of Oceanography, University of California, San Diego, La Jolla, California, and Groupe d'études de l'Atmosphère Météorologique, Centre National de la Recherche Scientifique,
Toulouse, France; SHINGLER AND WANG—Department of Chemical and Environmental Engineering, University of Arizona, Tucson, Arizona; WONASCHÜTZ-Department of Atmospheric Sciences, University of Arizona, Tucson, Arizona

*CURRENT AFFILIATION: Combustion Research Facility, Sandia National Laboratories, Livermore, California

CORRESPONDING AUTHOR: Lynn M. Russell, Scripps Institution of Oceanography, University of California, San Diego, 9500 Gilman Dr., Mail Code 022I, La Jolla, CA 92093-022I

E-mail: Imrussell@ucsd.edu

The abstract for this article can be found in this issue, following the table of contents.

DOI:10.1175/BAMS-D-12-00015.1

A supplement to this article is available online (10.1175/BAMS-D-12-00015.2)

In final form 9 August 2012

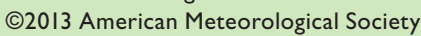


to increased aerosol levels be represented in theories and models of the climate system? Is it possible to extract observationally the cloud response to aerosols from that of the changing ambient meteorology? Our understanding, especially of warm-phase cloud microphysics, has advanced significantly in the last decade as a result of satellite observations, computational modeling, and field studies. Still, the challenge of untangling the effects of aerosol perturbations on clouds from those of meteorological variabil-

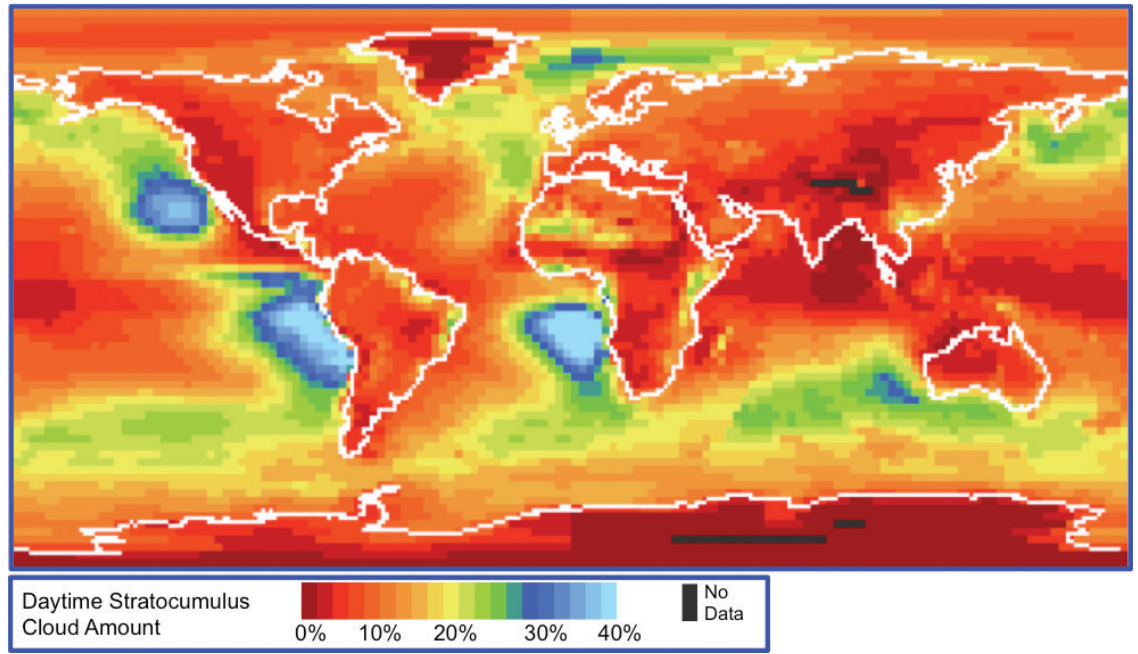

FIG. I. Daytime annual average stratocumulus cloud amount (\%) over the 1983-2009 period. Data obtained from International Satellite Cloud Climatology Project (ISCCP) D2 monthly means (http://isccp.giss.nasa.gov/products/ browsed2.html). ity itself and generalizing the findings from such studies to the scales that affect climate remains daunting. Aerosol properties tend to be highly variable, both spatially and temporally, in terms of size and chemical composition. While limited attempts have been made to employ particles of known size and composition in cloud perturbation studies, and thereby alleviate uncertainties associated with cloud activation, such attempts have proved difficult to implement. Here we describe a coordinated field experiment, the Eastern Pacific Emitted Aerosol Cloud Experiment (E-PEACE) campaign, in which the effects of well-defined aerosol perturbations on marine stratocumulus clouds were probed via in situ aircraft and satellite observations.

Key issues addressed in E-PEACE that have prevented accurate depiction of aerosol effects on clouds in large-scale models include:

1) What observations can constrain the overall effect of particles and the clouds that form on them on Earth's climate?

2) What is the specific effect of the distribution of particles by size on cloud droplet activation and cloud microphysics?

3) Can the effects of chemical makeup of particles be isolated from other cloud responses by seeding experiments?

MARINE STRATOCUMULUS AND CLIMATE. Stratocumulus clouds are characterized by their large spatial extent and are organized into distinctive patterns, often with rolling, linear structures.
They are primarily formed over the oceans and are a semipersistent feature in many regions adjacent to continents. The dynamical conditions that lead to their formation involve generation of convective currents below drier, stable air that prevents continued vertical development. Based on this, stratocumulus clouds are typically classified into three categories (Klein and Hartmann 1993). The first and most common category involves clouds forming over oceans with relatively cold sea surface temperatures with a boundary layer that is capped by a strong temperature inversion (maintained by large-scale subsidence). These systems are typically formed in regions near western continental boundaries, where trade winds blow from midlatitudes toward the intertropical convergence zone and generate cold sea surface temperatures. The convection that maintains the stratocumulus is driven by radiative cooling at the top of the boundary layer (Lilly 1968), while precipitation and entrainment are thought to represent key forcings that control the structure and stability of the boundary layer. While this study focuses on this first type of stratocumulus cloud because of their important role in radiative forcing on the global scale, another type of stratocumulus cloud is formed in winter over oceanic western boundary currents, where cold continental air flows over warm waters, and develops convection. Unlike the first category, convection is driven by strong surface heat fluxes (Schubert et al. 1979b,a). Finally, Arctic stratus is formed mostly in the summer and results from radiative cooling of subpolar moist air entrained into the Arctic (Curry et al. 1988). 
Considerable areas of subtropical and polar oceans are extensively covered with stratocumuli (Fig. 1). In the midlatitude oceans $\left(40^{\circ}-60^{\circ} \mathrm{N}, 50^{\circ}-65^{\circ} \mathrm{S}\right)$ maximum cloud cover occurs during the summer months and averages between $62 \%$ and $82 \%$; minimum cloud cover occurs in the winter and averages around 50\% (Klein and Hartmann 1993). In the subtropics, cloud cover is more variable (but still considerable), ranging from $35 \%$ to $72 \%$ during peak months and $17 \%-42 \%$ during minimum activity (Klein and Hartmann 1993). The shortwave cloud albedo forcing of stratocumulus is larger than its longwave cloud greenhouse forcing, resulting in a net cooling over the regions they cover. According to the Earth Radiation Budget Experiment (ERBE; Barkstrom 1984), the longwave cloud forcing of midlatitude stratocumulus is about $40 \mathrm{~W} \mathrm{~m}^{-2}$, while the shortwave forcing reaches a minimum of $-150 \mathrm{~W} \mathrm{~m}^{-2}$ in the Pacific and $-120 \mathrm{~W} \mathrm{~m}^{-2}$ in the Atlantic. The strong net forcing of approximately $-100 \mathrm{~W} \mathrm{~m}^{-2}$ is a cooling effect with considerable impacts on local and global climate (see "Ship tracks" for more information).

\section{RESPONSE OF MARINE STRATOCUMULUS TO AEROSOL PERTURBATIONS. There have} been several important measurement campaigns (Table 1) as well as a number of modeling studies (Table 2) aimed at characterizing the response of marine stratocumulus to aerosol perturbations, which we summarize here. The Monterey Area Ship Track (MAST) experiment in 1994 (Durkee et al. 2000c) was one of the first aircraft-based studies that included detailed characterization of aerosol and cloud droplet size distributions down to $20 \mathrm{~nm}$ and above $20 \mu \mathrm{m}$. This study tracked particle emissions from ships in stratocumulus cloud conditions, allowing identification of the effects of aerosol perturbations on cloud radiative signatures (Noone et al. 2000b,a). The Second Dynamics and Chemistry of the Marine Stratocumulus field study (DYCOMS II) consisted of nine nighttime flights west of San Diego, California, in July 2001 for testing large-eddy simulations of nocturnal stratocumulus (Stevens et al. 2003). A linear relationship between cloud condensation nuclei (CCN) and cloud droplet number emerged (Twohy et al. 2005), together with the drizzle-induced change in cloud structure (Van Zanten and Stevens 2005). A series of Cloud-Aerosol Research in the Marine Atmosphere (CARMA; Hegg et al. 2009) studies helped explain the source attribution of $\mathrm{CCN}$ and aerosol light scattering in the northeastern Pacific marine boundary layer. The Cloud Indirect Forcing Experiment (CIFEX) showed that aerosols over the northeastern Pacific Ocean (primarily from North American emissions) enhance the cloud drop
In 1966, Conover (1966) reported "anomalous cloud lines" present in visible-wavelength satellite images from Television and Infrared Observation Satellites (TIROSs). He noted that these lines, as much as $500 \mathrm{~km}$ long and up to $25 \mathrm{~km}$ in width, were likely due to liquid particles from the exhaust of oceangoing vessels. Twomey et al. (1968) remarked that the observations by Conover were consistent with the impact of additional CCN in a very clean marine boundary layer. Subsequent studies have strengthened the connection between ship exhaust and so-called ship tracks (e.g., Scorer 1987). Observations using near-infrared wavelengths from Advanced Very High Resolution Radiometer (AVHRR) exhibit more extensive features of ship effects on clouds (Coakley et al. 1987). Twomey (199I) showed that marine stratiform clouds may be particularly sensitive to additional CCN, leading to higher cloud droplet number concentration and increased cloud reflectivity (albedo).

In situ airborne measurements of ship tracks during the First ISCCP Regional Experiment (FIRE) in 1987 showed that droplet sizes in two ship tracks decreased significantly, accompanied by a higher liquid water content in the ship track than in the background (Radke et al. 1989); however, other satellite- and simulation-based studies have shown decreases in liquid water content (Coakley and Walsh
2002; Lu et al. 2009; Segrin et al. 2007). Albrecht (1989) proposed that the increase in liquid water content resulted from drizzle suppression in the ship tracks due to smaller droplet sizes and consequent retarded coalescence. Later, aircraft measurements off the Washington coast also noted the reduction of drizzle droplet numbers in the ship tracks (Ferek et al. 1998). The MAST experiment, which took place off the California coast in June 1994 (Durkee et al. 2000b), was designed to examine a series of hypotheses focused on links between the ship-emitted aerosol, mixing of the effluent through the boundary layer, and response in cloud droplets.

Remote sensing by advanced satellite instrumentation has been applied in a number of studies on ship tracks (e.g., Schreier et al. 2007; Segrin et al. 2007). Recent satellite studies using MODIS imagery (Christensen and Stephens 20II) have observed ship tracks embedded in different cloud structures. Cloud-Aerosol Lidar with Orthogonal Polarization (CALIOP) was used to determine the extent to which ship-emitted aerosols alter the important microphysical and macrophysical properties of marine stratocumulus across the North Pacific Ocean and off the coasts of South America and South Africa. The results show that aerosols change the microphysical and macrophysical responses of marine stratocumulus depending on mesoscale stratocumulus convective regimes. 
number concentration and reduce the drop size for marine stratocumulus and cumulus clouds, resulting in satellite-measured increases in cloud brightness (Wilcox et al. 2006).

The Marine Stratus/Stratocumulus Experiment (MASE) was carried out in two phases over the eastern Pacific Ocean off the coast of Monterey, California. The first phase (MASE-I) was undertaken in July 2005 (Lu et al. 2007), and the second phase (MASE-II) was conducted in July 2007 (Lu et al. 2009), each to evaluate aerosol-cloud-drizzle relationships in regions of uniform meteorology with localized aerosol enhancements in ship tracks. The ship-track regions exhibited a smaller cloud drop effective radius, higher cloud droplet number concentration, reduced drizzle drop number concentration, and higher liquid water content (LWC) than the adjacent clean regions; however, trends were obscured by spatial-temporal variability. Results from both individual case studies and ensembles of simulations in both MASE studies are in accord with those from other field campaigns (e.g., Brenguier et al. 2000; Feingold et al. 2006; Roberts et al. 2008; Wilcox et al. 2006), in that increased cloud drop number (CDN) concentration and decreased cloud-top effective radius are associated with increased subcloud aerosol concentration [at fixed liquid water path (LWP)]. The ship-track regions exhibited a smaller cloud drop spectral width and relative dispersion in MASE-I, in accord with large-eddy simulations (Lu and Seinfeld 2006). More polluted clouds were observed to have a smaller cloud-base drizzle rate; however, this did not equate to a larger amount of liquid water in that column of the atmosphere (LWP) when compared with clean clouds. Dynamic adjustment of the cloud in response to drizzle, in-cloud latent heating, subcloud evaporative cooling, and cloud-top entrainment would need to be taken into consideration (Ackerman et al. 2004; Lu and Seinfeld 2005). A new framework of precipitation susceptibility (Feingold and Siebert 2009; Sorooshian et al. 2009b), which quantifies the change in precipitation rate in response to aerosol perturbations, was applied in MASE-II.

The Variability of American Monsoon Systems (VAMOS) Ocean-Cloud-Atmosphere-Land Study Regional Experiment (VOCALS-REx) was conducted in the southeast Pacific off the coast of northern Chile during October and November 2008 to make

\begin{tabular}{|c|c|c|}
\hline Experiment & Publications & Key findings (for aerosol-cloud interactions) \\
\hline $\begin{array}{l}\text { MAST } \\
\text { (northeast Pacific) }\end{array}$ & $\begin{array}{l}\text { Russell et al. (1999) } \\
\text { Hobbs et al. }(2000) \\
\text { Frick and Hoppel }(2000) \\
\text { Durkee et al. }(2000 \mathrm{~b}) \\
\text { Noone et al. }(2000 \mathrm{~b}, \mathrm{a}) \\
\text { Ferek et al. }(2000)\end{array}$ & $\begin{array}{l}\text { Observed changes in drop distributions and LWC profile. } \\
\text { Ship emission characterization and size distributions. } \\
\text { Case studies of four ship emissions that produce ship tracks. } \\
\text { Test of aerosol-induced ship-track hypothesis. } \\
\text { Case studies illustrating background pollution effects on albedo sensitivity. } \\
\text { Drizzle and LWC changes in ship tracks relative to unperturbed clouds. }\end{array}$ \\
\hline $\begin{array}{l}\text { DECS } \\
\text { (northeast Pacific) }\end{array}$ & $\begin{array}{l}\text { Stevens et al. (2005) } \\
\text { Sharon et al. (2006) }\end{array}$ & $\begin{array}{l}\text { Rift POC study; variability in cloud drizzle characteristics due to natural } \\
\text { processes and emissions. }\end{array}$ \\
\hline $\begin{array}{l}\text { DYCOMS II } \\
\text { (nocturnal) } \\
\text { (northeast Pacific) }\end{array}$ & $\begin{array}{l}\text { Stevens et al. (2003) } \\
\text { Twohy et al. (2005) } \\
\text { Petters et al. (2006) } \\
\text { Hawkins et al. (2008) } \\
\text { Faloona et al. (2005) } \\
\text { Van Zanten and Stevens (2005) }\end{array}$ & $\begin{array}{l}\text { Characterization of POCs in nocturnal marine boundary layers. } \\
\mathrm{CN} / \mathrm{CCN} / \mathrm{CDN} \text { relationships are linear. } \\
\mathrm{CCN} \text { closure for marine boundary layer particles. } \\
\text { Composition independence of particle activation in the aged boundary layer. } \\
\text { Entrainment rates and variability in the nocturnal marine boundary layer. } \\
\text { Drizzle in nocturnal boundary layer in intense precipitation pockets. }\end{array}$ \\
\hline CIFEX & Wilcox et al. (2006) & $\mathrm{CCN}$ increases correlated to CDN and reflected radiation for constant LWP. \\
\hline $\begin{array}{l}\text { MASE-I/II } \\
\text { (northeast Pacific) }\end{array}$ & $\begin{array}{l}\text { Lu et al. }(2007,2009) \\
\text { Sorooshian et al. (2007) } \\
\text { Hersey et al. (2009) } \\
\text { Sorooshian et al. }(2009 b, a)\end{array}$ & $\begin{array}{l}\text { Ship tracks had smaller cloud drop effective radius, higher number } \\
\text { concentration } N_{\text {o }} \text {, reduced drizzle drop number, and larger cloud LWC } \\
\text { than adjacent clean regions; however, trends were obscured by spatial- } \\
\text { temporal variability. Aerosols above cloud tops are enriched with water- } \\
\text { soluble organic species, have higher organic volume fractions, and are less } \\
\text { hygroscopic relative to subcloud aerosol. }\end{array}$ \\
\hline CARMA & Hegg et al. (2009) & Source attribution of $\mathrm{CCN}$ and aerosol light scattering. \\
\hline $\begin{array}{l}\text { VOCALS-REx } \\
\text { (southeast Pacific) }\end{array}$ & $\begin{array}{l}\text { Bretherton et al. }(2010) \\
\text { Feingold et al. }(2010) \\
\text { Wood et al. (201la) }\end{array}$ & $\begin{array}{l}\text { Offshore drizzle not explained by CCN decrease. } \\
\text { Oscillations in aerosol concentrations correspond to precipitation cycles. } \\
\text { POC regions had enhanced drizzle and LWC. }\end{array}$ \\
\hline
\end{tabular}


observations of poorly understood but important components of the coupled climate system of the southeast Pacific (Allen et al. 2011; Bretherton et al. 2010; Wood et al. 2011a,b). VOCALS investigated links between aerosol, clouds, and precipitation and their impacts on stratocumulus radiative properties. Transition and feedbacks of mesoscale cellular convection were addressed (Wood et al. 2011a), as well as the modeling of microphysical and meteorological controls on precipitation and cloud cellular structure (Wang et al. 2010).

Of critical importance to the aerosol-cloud system is how the clouds themselves modify aerosol physicochemical properties, which consequently affects their ability to interact with radiation outside of clouds in addition to serving as CCN the next time the particles are entrained into cloud. Most particles in the marine boundary layer likely have at some point in their lifetime been inside a cloud. Simulations of typical parcel trajectories in the marine atmosphere have shown the impacts of cycling in and out of clouds on particle composition (Feingold et al. 1998). Of the limited studies that have examined cloud effects on aerosol in the northeastern Pacific region, there is evidence that clouds alter both the inorganic and organic fractions of aerosol (Crahan et al. 2004; Sorooshian et al. 2007), which can lead to different hygroscopic properties (Hegg et al. 2008; Hersey et al. 2009). These differing impacts of clouds on aerosol particles motivated the need for designing an experiment that would better constrain the influence of clouds on aerosol size, composition, and wateruptake properties.

E-PEACE. E-PEACE combined a targeted aircraft campaign off the coast of Monterey in July and August 2011 with embedded ship and satellite observations (Fig. 2) and modeling studies. Atmospheric conditions in the northeastern Pacific during July are ideal for the formation of homogeneous layers of persistent stratocumulus clouds. The layers observed have consistent diurnal characteristics, cloud thicknesses of 100-300 m, and cloud-top heights typically below $500 \mathrm{~m}$. The susceptibility of cloud albedo to particle perturbations is well documented for the eastern Pacific near $36^{\circ} \mathrm{N}$ (Coakley et al. 1987, 2000; Platnick et al. 2000).

We employed the research vessel (R/V) Point Sur to measure the aerosol below cloud and as a platform for well-characterized smoke emissions to produce a uniquely identifiable cloud signature. The Center for Interdisciplinary Remotely-Piloted Aircraft Studies (CIRPAS) Twin Otter aircraft was used with a full payload of instruments (Table 3) to measure particle and cloud droplet number, mass, and composition. E-PEACE combined 1) controlled release of smoke from the deck of the Point Sur, salt aerosol from the Twin Otter, and exhaust from container ships transiting across the study region; 2) flight plans designed to investigate results from large-eddy simulations (LES) and to provide constraints for aerosol-cloud parcel (ACP) modeling studies, to test

\begin{tabular}{|c|c|c|}
\hline Model type & Publications & $\begin{array}{l}\text { Key findings } \\
\text { (for aerosol-cloud interactions) }\end{array}$ \\
\hline ACP using observations & Russell et al. (1999) & Feedback effects of particles on supersaturation and LWC profile. \\
\hline ACP with LES trajectories & Feingold et al. (1998) & Sensitivity of cloud properties to variability in trajectories. \\
\hline $\begin{array}{l}\text { ACP with supersaturation } \\
\text { or updraft distributions }\end{array}$ & $\begin{array}{l}\text { Meskhidze et al. (2005) } \\
\text { Hsieh et al. (2009) }\end{array}$ & $\begin{array}{l}\text { Effectiveness of parameterization for accurate droplet activation. } \\
\text { Importance of maximum supersaturation rather than distribution. }\end{array}$ \\
\hline $\begin{array}{l}\text { LES-nocturnal } \\
\text { (northeast Pacific) }\end{array}$ & Hill et al. (2009) & Inhomogeneous mixing less important than particles. \\
\hline $\begin{array}{l}\text { LES } \\
\text { (Pacific/Atlantic) }\end{array}$ & Ackerman et al. $(2003,2004)$ & $\begin{array}{l}\text { LWP is reduced as CDN increases. } \\
\text { Nighttime CDN increases will suppress drizzle. }\end{array}$ \\
\hline $\begin{array}{l}\text { LES-diurnal } \\
\text { (Pacific/Atlantic) }\end{array}$ & Lu and Seinfeld $(2005,2006)$ & $\begin{array}{l}\text { Giant CCN increase drizzle in some conditions. } \\
\text { Relative dispersion increases apparent indirect effect. }\end{array}$ \\
\hline $\begin{array}{l}\text { LES-nocturnal } \\
\text { (northeast Pacific) }\end{array}$ & Savic-Jovcic and Stevens (2008) & Reduction in cloud albedo associated with drizzle. \\
\hline $\begin{array}{l}\text { LES } \\
\text { (southeast Pacific) }\end{array}$ & Caldwell and Bretherton (2009) & Diurnal cycle controls drizzle and LWP. \\
\hline Mixed layer & Wood et al. (2009) & Drizzle decreases cloud height and entrainment and CDN increases. \\
\hline LES & Sandu et al. (2009) & Vertical stratification affects LWP; diurnal transition effects on LWP. \\
\hline
\end{tabular}


our ability to quantitatively predict the cloud dynamical response to increases in particle concentrations in the natural atmosphere; and 3) satellite analyses of marine stratocumulus to constrain the radiative properties of the natural, perturbed, and regional cloud systems.

With 12 days of ship time on the R/V Point Sur and 30 flights (each $\sim 4.5 \mathrm{~h}$ long) on the CIRPAS Twin Otter (Tables 4 and 5), we could take full advantage of the persistence of stratocumulus clouds to probe the effect of particle sources on marine stratocumulus properties. Since the particles would be emitted in high concentrations over small areas in crosswind directions, their effects on clouds could be separated from those of meteorology. And in terms of number concentration and duration, the impacts of these particle emissions would be large enough to be distinguished from natural cloud variability.

As noted above, three types of particles were involved in E-PEACE: 1) combustion exhaust particles from cargo ships of opportunity, which are the emissions responsible for ship tracks; 2) shipboard smoke-generated particles; and 3) aircraft-based milled salt particles (Fig. 3). Type 1 is the exhaust that consists of 50-100-nm dry-diameter particles

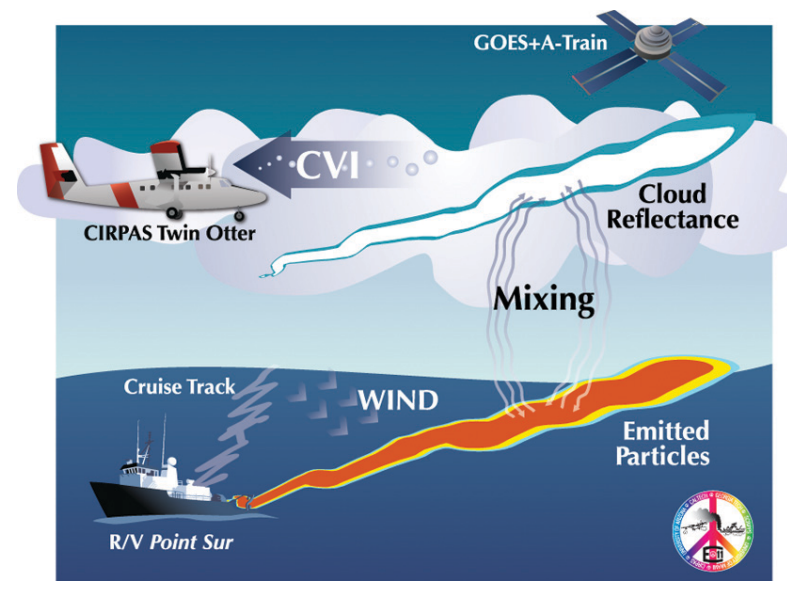

FIG. 2. Illustration of E-PEACE design and observations of emitted particles in marine stratocumulus in Jul and Aug 201 I west of central California. The diagram shows the three platforms used in making observations of particle and cloud chemical and physical properties, namely, the R/V Point Sur, the CIRPAS Twin Otter, and the A-Train satellites and GOES. The design included using smoke generated on board the R/V Point Sur that was measured after emission by the CIRPAS Twin Otter in clouds. The satellite was used to measure the changes in reflectance of sunlight due to the effects of the emitted particles on the clouds. The CVI was used as an inlet for evaporating droplets as they were brought into the aircraft, allowing sampling of droplet chemical composition. emitted at rates of $10^{16}-10^{18} \mathrm{~s}^{-1}$ from the engines of large (2,000 ton) cargo ships, in this instance on trans-Pacific, Los Angeles to San Francisco, or other commercial routes. Such emissions were responsible for the first observed ship tracks (Conover 1969). At a fuel cost of about $\$ 100,000$ (U.S. dollars) per day, operations of such vessels dedicated solely to research are not feasible. However, real-time tracking of commercial vessels (www.marinetraffic.com) was used to identify fast-moving $\left(>30 \mathrm{~km} \mathrm{~h}^{-1}\right)$ cargo or container ships in the region within the aircraft operating area (as illustrated in Fig. 4). Type 2 involves smoke particles produced at an estimated rate of $10^{11}-10^{13} \mathrm{~s}^{-1}$ on the stern deck of the R/V Point Sur (described in "Tailor-made particles with a battlefield smoke generator"), with dry diameters that ranged from $50 \mathrm{~nm}$ up to $1 \mu \mathrm{m}$ and very low hygroscopicity. Type 3 particles were dispersed from the Twin Otter aircraft in cloud. An adjustable auger fed a fluidized bed that dispensed $\mathrm{NaCl}$ particles, which had been milled to diameters of $3-5 \mu \mathrm{m}$ and mixed with $\mathrm{SiO}_{2}$ to prevent particles from sticking together (Drofa et al. 2010).

CLOUD ALBEDO EFFECTS. In situ observations provide measurements of aerosol and cloud microphysics on spatial scales relevant to individual clouds and therefore are a critical element in understanding aerosol-cloud effects. To extrapolate from individual clouds to obtain a statistically robust assessment of aerosol effects on clouds and precipitation requires corresponding satellite observations. We used visible and infrared imagery in near-real time from Geostationary Operational Environmental Satellites (GOESs; 30-min delay at www.nrlmry .navy.mil/sat-bin/epac_westcoast.cgi) and higherresolution images from the A-Train constellation of satellites (Stephens et al. 2002) for postexperiment analyses (illustrated in the top right of Fig. 2). The relevant satellite-based platforms in the eastern Pacific region include Terra and Aqua, which collectively provide retrievals of aerosol parameters (e.g., aerosol index) and cloud microphysical properties (e.g., drop effective radius, cloud optical depth). In this project we isolated aerosol-induced changes in these properties by creating tracks with unique geometry in different cloud regimes.

We used the zigzag pattern of the R/V Point Sur to create a track in cloud that was easily distinguishable from natural cloud characteristics and was broader than the constant-heading tracks made by ships in transit. These characteristics allowed us to track the plume with the CIRPAS aircraft and to isolate the effects from the smoke generated on the R/V Point Sur. 
TABLE 3. Instruments on CIRPAS Twin Otter and R/V Point Sur. PMIO = particulate matter $\leq 10 \mu \mathrm{m}$.

\begin{tabular}{|c|c|c|}
\hline Instruments & R/V Point Sur & CIRPAS Twin Otter \\
\hline $\begin{array}{l}\text { Particle and droplet } \\
\text { inlets }\end{array}$ & PMIO & $\mathrm{PMI}$ and $\mathrm{CVI}{ }^{\mathrm{a}}$ \\
\hline $\begin{array}{l}\text { Particle size } \\
\text { distributions }\end{array}$ & $\begin{array}{l}\text { CPC } 3010^{\mathrm{b}} \text { for diameters }>10 \mathrm{~nm} \\
\text { Scanning DMA } \\
\text { OPS } \\
\text { APS }\end{array}$ & $\begin{array}{l}\text { CPC } 3010^{\mathrm{b}} \text { for diameters }>10 \mathrm{~nm} \\
\text { CPC } 3025^{\mathrm{d}} \text { for diameters }>3 \mathrm{~nm} \\
\text { Scanning DMA } \\
\text { PCASP }\end{array}$ \\
\hline $\begin{array}{l}\text { Particle chemical } \\
\text { composition }\end{array}$ & $\begin{array}{l}\text { High-resolution (HR) ToF-AMS } \\
\text { SP2 } \\
\text { FTIR functional group composition } \\
\text { XRF elemental composition } \\
\text { PILS-TOC for water-soluble organic carbon }{ }^{\text {h }}\end{array}$ & $\begin{array}{l}\text { Compact (C) ToF-AMSs } \\
\text { SP2 }\end{array}$ \\
\hline Particle properties & $\begin{array}{l}\text { Tandem scanning and humidified DMAs } \\
\text { CCN spectrometer }\end{array}$ & $\begin{array}{l}\text { CCN spectrometer } \\
\text { Particle soot absorption photometer (PSAP) } \\
\text { Photoacoustic soot spectrometer, three wavelengths (PASS-3) }\end{array}$ \\
\hline $\begin{array}{l}\text { Droplet and drizzle } \\
\text { distributions }\end{array}$ & & $\begin{array}{l}\text { Phase Doppler interferometer (PDI) } \\
\text { CAS } \\
\text { CIP } \\
\text { Cloud droplet probe (CDP)' } \\
\text { Forward Scattering Spectrometer Probe (FSSP) } \\
\text { CIP-2D } \\
\text { Gerber light diffraction for LWC (particulate volume monitor } \\
\text { model PVM-100) }\end{array}$ \\
\hline $\begin{array}{l}\text { Droplet residual } \\
\text { properties (by CVI) }\end{array}$ & & $\begin{array}{l}\text { CPC } 3010^{\mathrm{b}} \text { for diameters }>10 \mathrm{~nm} \\
\text { CPC } 3025^{\mathrm{d}} \text { for diameters }>3 \mathrm{~nm} \\
\text { Scanning DMA } \\
\text { CCN spectrometer } \\
\text { C ToF-AMS } \\
\text { SP2 } \\
\text { PASS-3 }\end{array}$ \\
\hline $\begin{array}{l}\text { Cloud water } \\
\text { composition }\end{array}$ & & Slotted cloud water collector ${ }^{m}$ \\
\hline $\begin{array}{l}\text { Meteorological } \\
\text { variables }\end{array}$ & $\begin{array}{l}\text { Temperature } \\
\text { Relative humidity } \\
\text { Pressure } \\
\text { Wind speed and direction } \\
\text { Altitude and GPS location }\end{array}$ & $\begin{array}{l}\text { Temperature } \\
\text { Relative humidity } \\
\text { Pressure } \\
\text { Wind speed and direction, gust velocity } \\
\text { Altitude and GPS location }\end{array}$ \\
\hline Cloud structure & Ceilometer (cloud-base height) & Upward-facing Doppler radar ${ }^{n}$ \\
\hline Seawater properties & $\begin{array}{l}\text { Sea surface temperature } \\
\text { Chlorophyll-A }\end{array}$ & \\
\hline Particle generators & Oil smoke generator & Giant salt dispenser \\
\hline
\end{tabular}

${ }^{a}$ CVI (Shingler et al. 2012).

${ }^{b}$ Condensation particle counter (CPC) model 3010 (TSI, Inc.).

c Scanning DMA (Brechtel Manufacturing, Inc.).

${ }^{d}$ CPC model 3025 (TSI, Inc.).

e Scanning DMA models $308 \mathrm{I}$ and 3010 (TSI, Inc.).

${ }^{f}$ High-resolution time-of-flight aerosol mass spectrometer (Aerodyne Research, Inc.).



h Particle-into-liquid sampler (Brechtel Manufacturing, Inc.) coupled to a total organic carbon analyzer (Sievers model 800; Sullivan et al. 2006).

iScanning and humidified scanning DMA (Brechtel Manufacturing, Inc.; Sorooshian et al. 2012).

i CCN spectrometer (Moore and Nenes 2009).

${ }^{k}$ CCN spectrometer [miniaturized from the design of Roberts and Nenes (2005)].

' Cloud droplet probe (Droplet Measurement Technology; Lance et al. 20I0).

m Modified Mohen design (based on Hegg and Hobbs 1986).

n 94-GHz frequency-modulated continuous wave cloud radar. 


\begin{tabular}{|c|c|c|c|c|c|}
\hline Flight & Date & Description of clouds and particle sources sampled & $\begin{array}{l}\text { Cloud level } \\
(\mathrm{m})\end{array}$ & $\begin{array}{l}\text { Background } \\
\text { LWC* }\end{array}$ & $\begin{array}{l}\text { Track } \\
\text { LWC* }\end{array}$ \\
\hline I & 8 Jul & Thin cloud layer; salt seeding & $257-362$ & 0.15 & - \\
\hline 2 & 9 Jul & Thick, wet cloud layer, drizzling; salt seeding & $283-570$ & 0.28 & - \\
\hline 3 & I3 Jul & Broken clouds; smoke sampling** & - & - & - \\
\hline 4 & 14 Jul & High, thick cloud layer; smoke sampling & $651-934$ & 0.15 & 0.22 \\
\hline 5 & I5 Jul & $\begin{array}{l}\text { Two broken cloud layers; cargo ships (Ice Blizzard); smoke } \\
\text { sampling }\end{array}$ & $266,550-794$ & 0.14 & 0.12 \\
\hline 6 & 16 Jul & Two broken cloud layers; smoke sampling & $142,550-774$ & 0.12 & 0.12 \\
\hline 7 & I7 Jul & No clouds; cargo ships (Hanjin Montevideo); smoke sampling & - & 0.19 & - \\
\hline 8 & 19 Jul & $\begin{array}{l}\text { Thick, wet cloud layer, no drizzle; cargo ships (Cap Preston); } \\
\text { smoke sampling }\end{array}$ & $258-533$ & 0.21 & 0.25 \\
\hline 9 & $2 \mathrm{l} \mathrm{Jul}$ & Thick cloud layer, drizzling; cargo ship; smoke sampling & $212-533$ & 0.27 & 0.30 \\
\hline 10 & 22 Jul & Thick cloud layer, intermittent drizzling; smoke sampling & $235-551$ & 0.30 & 0.35 \\
\hline II & $23 \mathrm{Jul}$ & Thick cloud layer; smoke sampling; cargo ships (Pos Yantian) & $308-630$ & 0.28 & 0.26 \\
\hline 12 & $24 \mathrm{Jul}$ & Mostly clear air, high clouds; cargo ships (Ken Ryu) & $492-779$ & 0.17 & 0.18 \\
\hline 13 & $26 \mathrm{Jul}$ & $\begin{array}{l}\text { Thick cloud layer; cargo ships (SCF Samotlor, Vinalines Galaxy, } \\
\text { Gluecksburg); salt seeding }\end{array}$ & $253-560$ & 0.26 & 0.31 \\
\hline 14 & $27 \mathrm{Jul}$ & Low, thick cloud layer; cargo ship (Mol Earnest) & $|3|-44 \mid$ & 0.24 & 0.32 \\
\hline 15 & $28 \mathrm{Jul}$ & $\begin{array}{l}\text { Thin cloud layer; cargo ship (Hanjin Hamburg, Ever Develop, Cap } \\
\text { Preston) }\end{array}$ & $267-413$ & 0.17 & 0.15 \\
\hline 16 & $29 \mathrm{Jul}$ & $\begin{array}{l}\text { High, wet clouds, no drizzle; cargo ship (MSC Fabienne); salt } \\
\text { seeding }\end{array}$ & $265-534$ & 0.30 & 0.33 \\
\hline 17 & I Aug & Thin, high cloud layer; cargo ship (Astro Phoenix) & $641-784$ & 0.15 & 0.13 \\
\hline 18 & 2 Aug & $\begin{array}{l}\text { Thick, wet cloud layer, drizzling; cargo ships (Riga, Australia } \\
\text { Express); salt seeding }\end{array}$ & $310-613$ & 0.27 & 0.44 \\
\hline 19 & 3 Aug & $\begin{array}{l}\text { Thick cloud layer, some drizzle; cargo ships (Xin Ya Zhou); salt } \\
\text { seeding }\end{array}$ & $309-628$ & 0.23 & 0.31 \\
\hline 20 & 4 Aug & Cumulus-like broken clouds, drizzling; cargo ships (YM Cypress) & $294-633$ & 0.17 & 0.18 \\
\hline 21 & 5 Aug & Low cloud layer, intermittent drizzle; cargo ships (Nelvana) & $|69-50|$ & 0.28 & 0.27 \\
\hline 22 & 8 Aug & Thin cloud layer & $281-448$ & 0.22 & - \\
\hline 23 & 9 Aug & Thin cloud layer & $324-485$ & 0.21 & - \\
\hline 24 & 10 Aug & $\begin{array}{l}\text { Low clouds, intermittent drizzle; cargo ships (Tian Shang He); salt } \\
\text { seeding }\end{array}$ & $286-553$ & 0.29 & 0.31 \\
\hline 25 & II Aug & Two broken cloud layers; cargo ships (NYK Artemis) & $216,440-600$ & 0.16 & 0.24 \\
\hline 26 & 12 Aug & Thick cloud layer; shipping lane; polluted layer above clouds & $278-578$ & 0.24 & - \\
\hline $27 a, b, c$ & 15 Aug & No clouds; north/south survey & - & - & - \\
\hline $28 a, b, c$ & 16 Aug & Low cloud layer; north/south changes in cloud amount & $136-379$ & 0.13 & - \\
\hline $29 a, b$ & I7 Aug & Low cloud layer; north/south survey & $156-366$ & 0.21 & - \\
\hline $30 a, b$ & 18 Aug & Low cloud layer; north/south survey & $142-352$ & 0.23 & - \\
\hline
\end{tabular}

* LWC $\left(\mathrm{g} \mathrm{kg}^{-1}\right)$ calculated as a flight average for all LWC $>0.1 \mathrm{~g} \mathrm{~kg}^{-1}$ (using measurements from the Gerber probe). Background and track concentrations were separated for each flight using the PCASP concentration thresholds set for each day: $80 \mathrm{~cm}^{-3}$ for $14 \mathrm{Jul}$;


28, 29 Jul and 2 Aug.

**Some datastreams were corrupted on flight 3 , so it is not shown in Fig. 6. 
TABLE 5. Summary of R/V Point Sur cruise during E-PEACE $201 \mathrm{I}$.

\begin{tabular}{|c|c|c|c|c|}
\hline Date & Description of clouds and smoke generation operations & Cloud bases $^{a}$ & SST & Surface wind ${ }^{\mathrm{c}}$ \\
\hline $12 \mathrm{Jul}$ & Multiple cloud layers; testing smoke generators & $70,160,430$ & 12.8 & 8 at $270^{\circ}$ \\
\hline $13 \mathrm{Jul}$ & Multiple cloud layers, light winds; intermittent smoke generation & $100,190,360$ & 13.1 & $5-20$ at $270^{\circ}$ \\
\hline I4 Jul & High clouds; smoke generation $(6 \mathrm{~h})$ & 420,660 & 13.9 & $15-20$ at $310^{\circ}$ \\
\hline I5 Jul & Broken low and high clouds; smoke generation (6 h) & 250,570 & 14.7 & 15 at $330^{\circ}$ \\
\hline $16 \mathrm{Jul}$ & Multiple cloud layers; smoke generation (6 h); plume sampling & $70,160,{ }^{d} 310$ & 13.7 & $<5$ at $330^{\circ}$ \\
\hline I7 Jul & Multiple broken cloud layers; smoke generation (5 h); plume sampling & $50,150,810,930$ & 14.6 & $5-10$ at $330^{\circ}$ \\
\hline $18 \mathrm{Jul}$ & Multiple broken cloud layers; smoke generation (I h); plume sampling & 60,160 & 15.7 & $8-10$ at $250^{\circ}$ \\
\hline $19 \mathrm{Jul}$ & Scattered low and high clouds; smoke generation (6 h) & $50,140,340$ & 14.6 & $15-20$ at $340^{\circ}$ \\
\hline $20 \mathrm{Jul}$ & Scattered clouds; smoke generation (I h) & $280^{d}$ & 14.5 & $15-20$ at $330^{\circ}$ \\
\hline $21 \mathrm{Jul}$ & Low, uniform clouds; smoke generation (5 h) & $210^{d}$ & 14.1 & $15-20$ at $330^{\circ}$ \\
\hline $22 \mathrm{Jul}$ & Low, uniform clouds; smoke generation ( 5 h) & $250,{ }^{d} 340$ & 13.9 & $18-22$ at $330^{\circ}$ \\
\hline $23 \mathrm{Jul}$ & Low, uniform clouds; smoke generation $(6 \mathrm{~h})$ & 290,420 & 14.4 & $4-8$ at $300^{\circ}$ \\
\hline
\end{tabular}

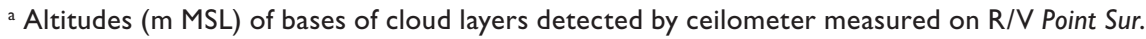

b Sea surface temperatures $\left({ }^{\circ} \mathrm{C}\right)$ measured on R/V Point Sur.

' Wind speed $\left(1 \mathrm{kt}=0.5144 \mathrm{~m} \mathrm{~s}^{-1}\right)$ and direction measured on R/V Point Sur.

${ }^{d}$ Clouds in which ship tracks were observed in the region.
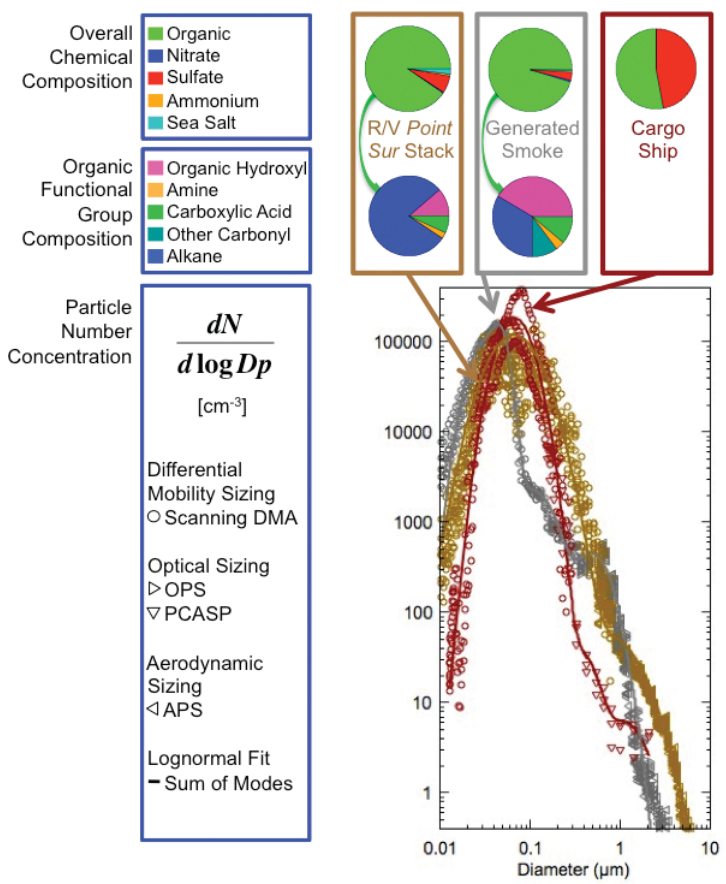

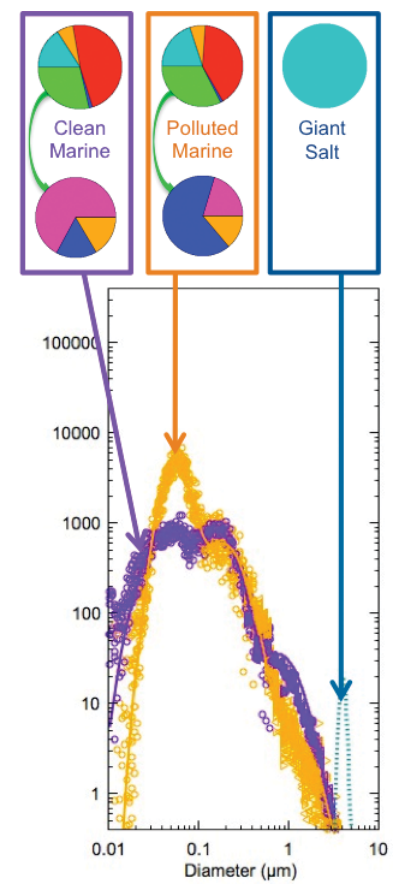

FIG. 3. Distribution by size of the number and submicron composition of particles emitted for E-PEACE, with comparison to both clean and polluted marine background particles measured during the experiment. Composition illustrates the overall massbased chemical composition, based on AMS and X-ray fluorescence (XRF; where we have calculated sea salt mass from $1.47 \times \mathrm{Na}+\mathrm{Cl}$, which was equal to summed components $\mathrm{Na}+\mathrm{Mg}+\mathrm{Cl}+\mathrm{Ca}$ $+K+$ non-sea-salt sulfate), and the organic functional group composition, based on Fourier transform infrared (FTIR) spectroscopy, with the box colors and arrows indicating the size distribution to which each composition corresponds. Organic functional

group composition was not available for the giant generated salt (since there was none) and the cargo ship (since sufficient sampling time was not available). The concentration of giant generated salt has been scaled by $10^{4}$, so that the particle size can be shown on the same graph. Measurements collected on the R/V Point Sur [0.01 < scanning differential mobility analyzer (DMA) $<0.9 \mu \mathrm{m}, 0.4<$ optical particle sizer (OPS) $<10 \mu \mathrm{m}$, $0.5<$ aerodynamic particle sizer (APS) $<15 \mu \mathrm{m}$ ] included the smoke generator (1210-1225 LT I7 Jul), the R/V Point Sur's stack emissions (2000-2200 LT 22 Jul), and background aerosol for clean (I100-II35 LT 20 Jul) and polluted (0220-0400 LT $19 \mathrm{Jul})$ marine conditions. Measurements of cargo ship emissions ( $0.0 \mathrm{I}<\mathrm{scanning}$ DMA $<0.9 \mu \mathrm{m}, 0.1<$ PCASP $<2 \mu \mathrm{m}$ ) were collected on the Twin Otter (1200-1315 LT I0 Aug). 
Note the satellite image on 16 July 2011 during the 1430 local time (LT) overpass of Aqua (Fig. 5), in which the part of cloud affected by the smoke is whiter (i.e., more reflective at $2.2 \mu \mathrm{m}$ ) than the surrounding clouds. To confirm this identification, we calculated and plotted the expected location of the smoke (given the average wind speed near the sea surface) at the time of the satellite overpass. Even without this simple calculation, the resemblance between the patterns of the ship path and the reflected track in cloud is evident.

We also identified tracks of cargo ships in satellite images similar to historical and recent work (Coakley et al. 1987; Durkee et al. 2000c; Segrin et al. 2007). At least three examples of these tracks from cargo or container ships are visible in the bottom left of Fig. 5 . The increase in the reflectance of the cloud tracks from cargo ships ( $15 \%$ mean increase at $545-565 \mathrm{~nm}$ for all tracks identified in the E-PEACE region in July and August 2011) was similar to the cloud tracks formed from smoke emitted from the R/V Point Sur
(14\% increase at 545-565 $\mathrm{nm}$ ). These increases are well within the range reported by Durkee et al. (2000a). For comparison, many ship tracks in the E-PEACE region had lower increases, and Chen et al. (2012) found that $30 \%$ of ship tracks during E-PEACE resulted in reduced reflectance.

\section{PARTICLE AND DROPLET NUMBER AND \\ COMPOSITION. The Twin Otter aircraft flew into} the same clouds shown in the satellite image (Fig. 5) to measure both the chemical composition and number of cloud droplets that caused the increased shortwave reflectance. Figure 6 shows the number of particles below cloud and droplets in cloud, and the pie graphs show that these droplets were almost entirely organic components with trace amounts of sulfate. The measured ship and marine characteristics of the organic components during E-PEACE were used to quantify the widespread contributions of ship emissions to the marine boundary layer aerosol (Coggon et al.
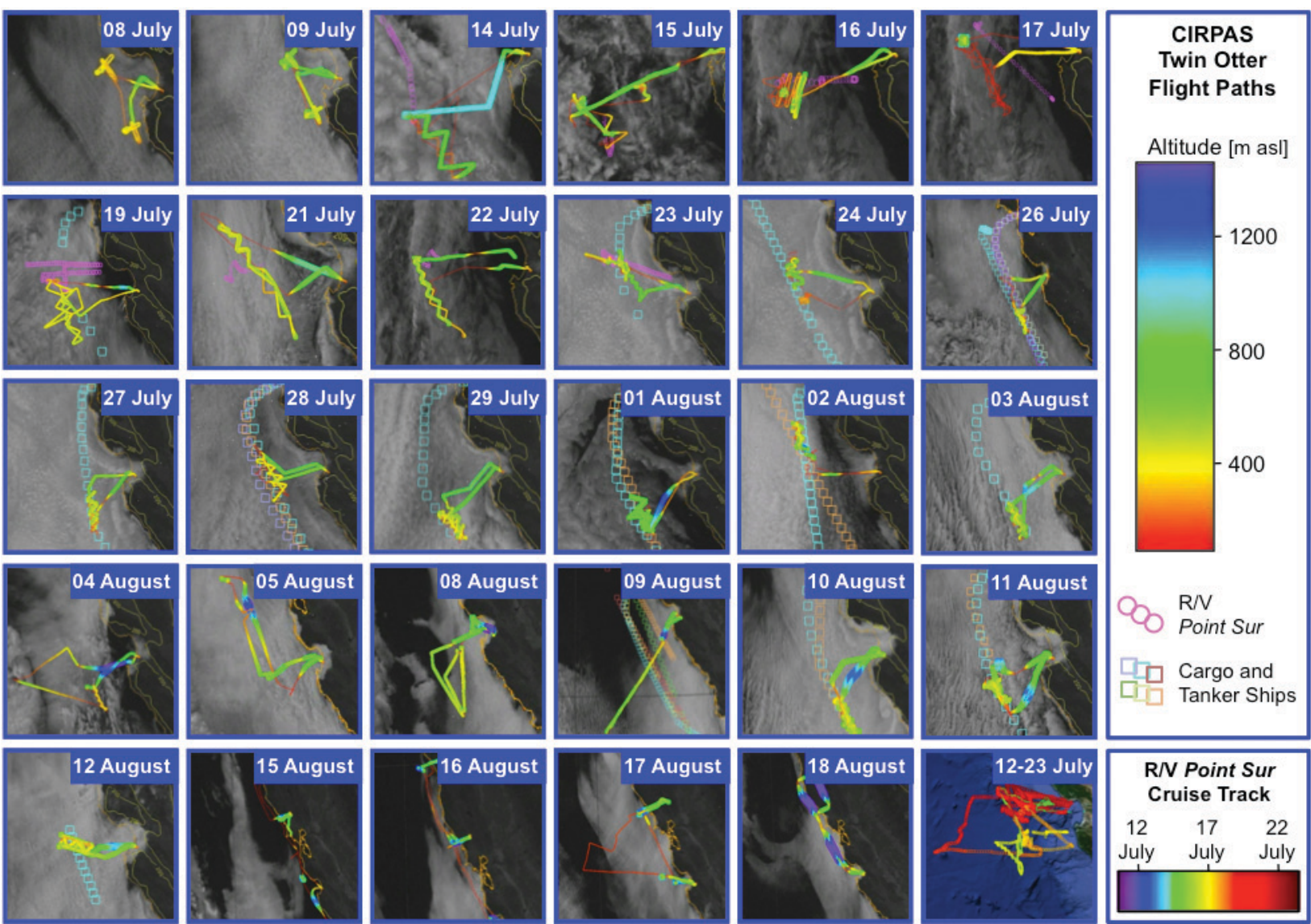

FIG. 4. Summary of the CIRPAS Twin Otter research flight paths and the R/V Point Sur cruise track. The first 29 panels show the CIRPAS Twin Otter flight path, colored by altitude MSL, overlaid on a GOES image of the cloud cover from that day. The tracks of the R/V Point Sur as well as cargo and tanker ships that were targeted for sampling that day are also shown. The last panel shows the I2-day cruise track of the R/V Point Sur, colored by date, overlaid on a Google Earth image of the topography. 
2012). The large organic fraction in Fig. 6a is characteristic of smoke emitted from the generators on the R/V Point Sur (see "Giant CCN stratocumulus cloud seeding") and contrasts with the composition of droplets in the cloud not affected by the smoke (Fig. 6c), which are made up of three-quarters sulfate and very little organic components. Interestingly, the particles that activated to form cloud droplets were sufficiently large (>1.1 $\mu \mathrm{m}$; see Table 6 ) to make activation possible even in the near absence of soluble ions (approaching the so-called Kelvin limit).

The chemical composition of the cloud droplets was measured using a specialized inlet that separates the droplets from smaller interstitial aerosol

\section{TAILOR-MADE PARTICLES WITH A BATTLEFIELD SMOKE GENERATOR}

moke emissions were generated on the stern of the $\int_{R / V}$ Point Sur by two U.S. Army-issued smoke generators (Fig. SBI) that were manufactured in approximately 1980 for use as battlefield obscurants, purchased in 2005, and refurbished. The pulse jet engines employ standard gasoline in a fuel injector head that was ignited by manually pumping the air pressure to 60 psi before generating a spark with a grating device. The engine was used to pump and heat paraffin-type oil so that it vaporizes (but does not ignite) at approximately $150^{\circ} \mathrm{C}$ (the flash point). The oil pumps were modified at sea using pressurized air to force the pistons, likely required to offset the effects of rusting over time. Maintenance was required hourly to clean the fuel injectors and adjust the fuel and oil delivery rates to optimize the fuelto-air ratio and temperature in the engine.

The vaporized oil was released through three nozzles into the atmosphere, where it condensed as droplets that range from $200 \mathrm{~nm}$ to $8 \mu \mathrm{m}$ in diameter (Fig. 3). Some oil was emitted as vapor, producing a second smaller mode of particles from oxidized organic components about $100 \mathrm{~nm}$ in diameter. The generators ran close to their design values, consuming approximately 5 gal of gasoline and one barrel (55 gal) of oil every hour. Paraffin-type oil is used in similar amounts by skywriting activities, where each three-word message takes about one hour of flight time and consumes one barrel of oil. At $10,000 \mathrm{ft}$, the lifetime of oil particles is likely seven days, 2-3 times longer than that of surface-emitted particles. The Library of Congress describes the use of this oil in skywriting as "environmentally safe" (www .loc.gov/rr/scitech/mysteries /skywriting.html).

We operated the smoke generators from 12 to 23 July from approximately dawn until noon, following a zigzag pattern similar to that shown in Fig. 2. (Videos of smoke-generating operations are available as supplemental material at the Journals Online website at http://dx.doi .org/I0.II75/BAMS-D-I2-000I5.2.) We were restricted to headings into the wind by a net $5 \mathrm{kt}$ or more to prevent eddies generated by the ship superstructure from carrying smoke backward into the cabins. This meant that in lower wind conditions, the smoke trail became more concentrated. In winds slower than the ship speed (10 kt), we were able to reverse course and measure the composition and number of particles in the smoke. These particles were $97 \%$ organic components, lacking both the $\sim 50 \%$ sulfate typically found in cargo ships burning bunker fuel and the $\sim 5 \%$ sulfate found in the R/V Point Sur emissions from marine diesel (Fig. 3). This unique, almost purely organic composition provided a fingerprint for tracking the smoke in cloud, as well as a surrogate for tracking particle properties in clouds.

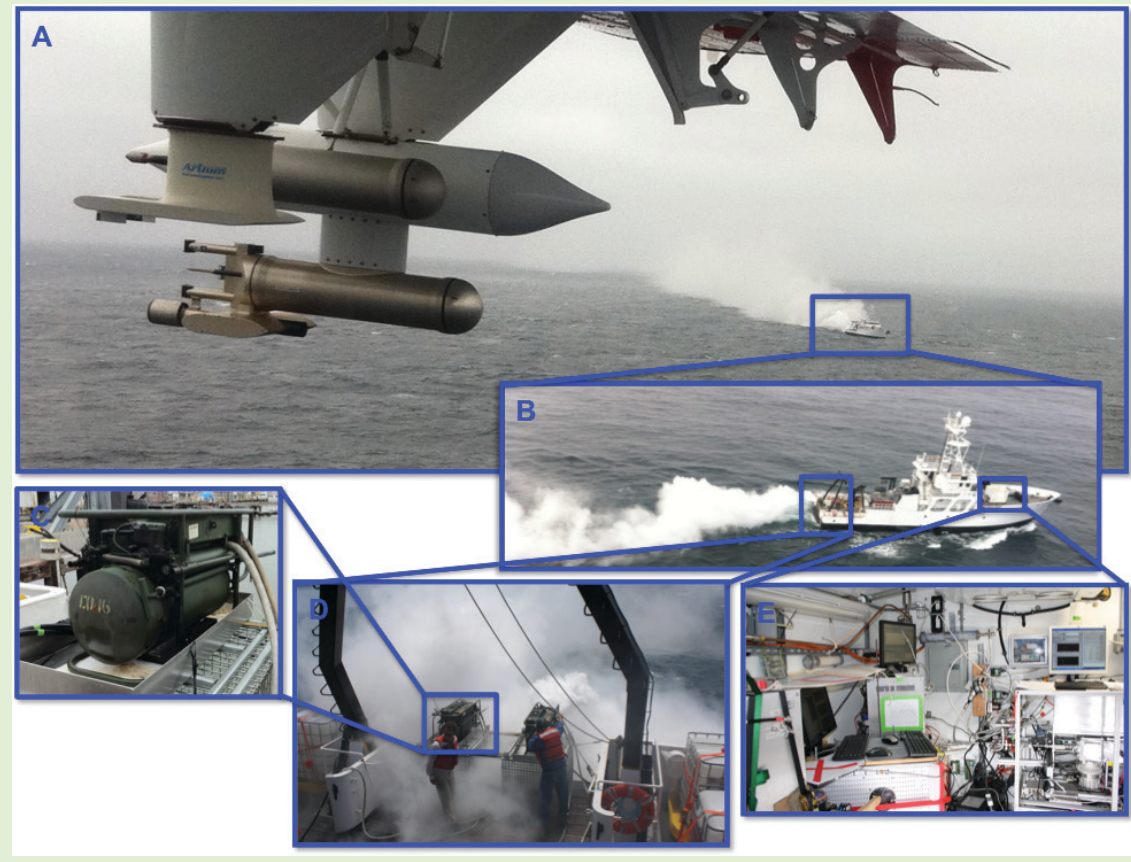

FIG. SBI. Photographs of the R/V Point Sur from the CIRPAS Twin Otter, showing (a) the persistence of the plume of smoke from the ship in the atmosphere and some of the aircraft instruments for measuring particles and clouds, (b) the production of smoke, (c) one of the two smoke generators used for producing smoke, (d) the operation of the smoke generators on the stern of the R/V Point Sur, and (e) the aerosol instrumentation on the bow of the R/V Point Sur. 
particles (i.e., the particles that did not activate into droplets). This kind of inlet is called a counterflow virtual impactor (CVI) because it uses airstreams forced to flow in different directions to separate larger momentum droplets from smaller particles. The isolated droplets are then evaporated and the chemical composition of the droplet residual particles is measured using an Aerodyne aerosol mass spectrometer (AMS) and other instruments on board the aircraft (see Table 3). Note that the CVI used in E-PEACE is a new design that exhibits a wellcharacterized $50 \%$ lower cutoff diameter $(11 \mu \mathrm{m})$ corresponding to the specific aircraft speed and CVI flow rate conditions experienced (Shingler et al. 2012). Periods with extensive drizzle, as identified with a cloud imaging probe (CIP), were omitted from this analysis owing to potential artifacts associated with the breakup of large drops.

We also measured cloud droplets in tracks produced by cargo ships (Fig. 6b) and compared them to the surrounding clouds (Fig. 6d). The droplets in clouds affected by the cargo ship emissions contained slightly less than $50 \%$ organic components, consistent with particle measurements in cargo ship emissions (Fig. 3). Roughly 5 times as many droplets are in the track from the cargo ship than in the cloud perturbed by the organic smoke generated on the R/V Point Sur, although each is about twice the background droplet number concentration for that day. Droplets in both tracks are smaller than those in the background, with the cargo ship droplets being the smallest, having the peak in the CDN concentration near $11.8 \mu \mathrm{m}$

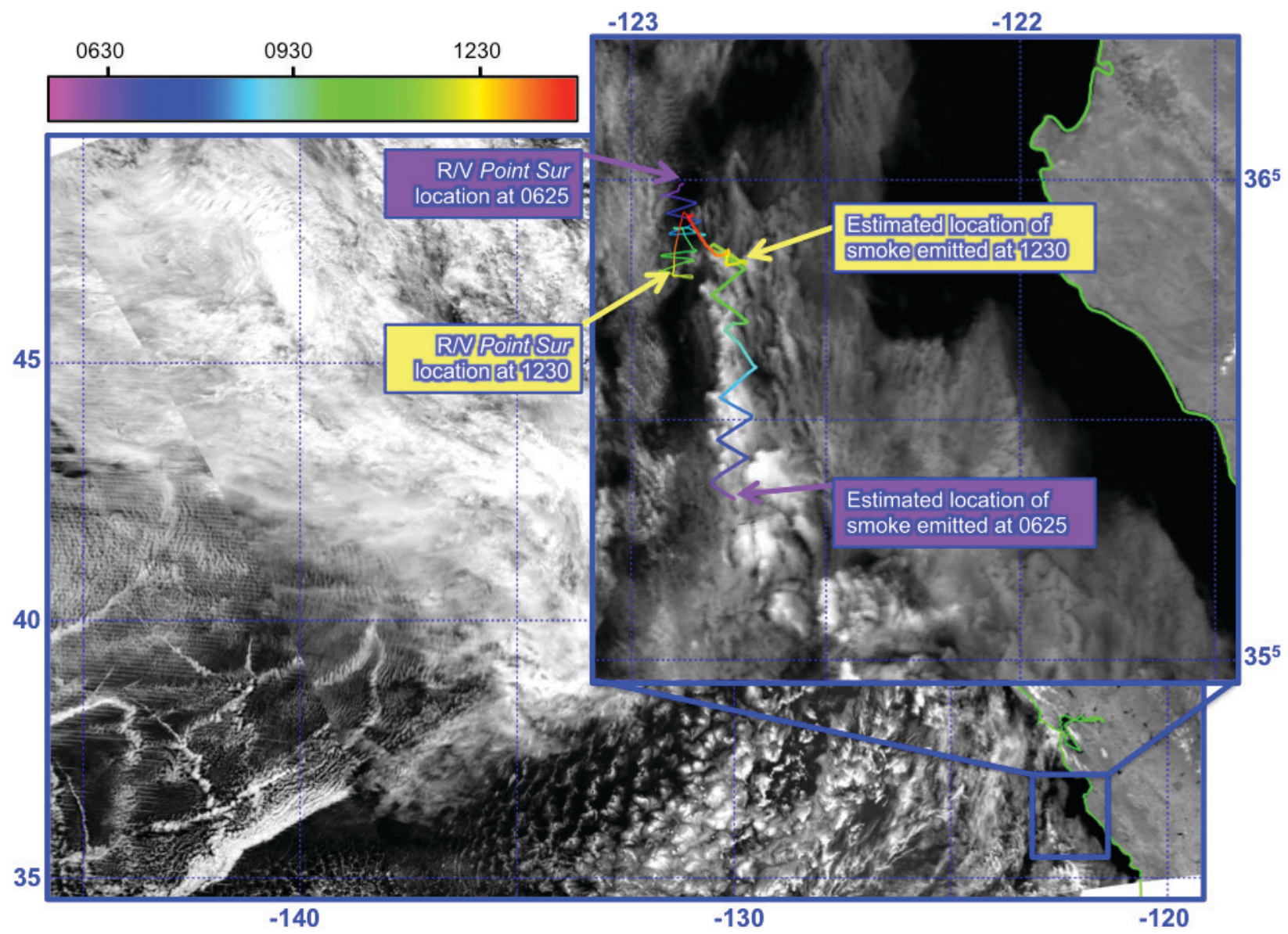

FIG. 5. Cloud tracks from cargo ships and the smoke produced on the R/V Point Sur. The larger image shows a composite of Aqua and Terra Moderate Resolution Imaging Spectroradiometer (MODIS) satellite images in the 2.2- $\mu \mathrm{m}$ channel. The Terra overpass (southwestern section of the composite image) occurred at I250 LT and the Aqua overpass occurred at 1430 LT $16 \mathrm{Jul} 201 \mathrm{I}$. The smaller inset image at top right shows an enlargement of the smoke track from the region indicated. The colored lines indicate the time at which the R/V Point Sur was at the location, indicated by the color bar (thin line) and the estimated location of particles emitted at the time of the color bar (thick line) at the time of the satellite overpass (I430 LT). The location of emitted particles was estimated using the time between the emission and the satellite overpass, scaled by the average wind speed and direction in the boundary layer. 
compared to $18.6 \mu \mathrm{m}$ from the smoke. But the difference in the background cloud droplet diameter is quite striking between the two days $(14.3 \mu \mathrm{m}$ on 10 August and $26.5 \mu \mathrm{m}$ on 16 July). The larger drop diameter on 16 July likely results from both the lower supersaturation $(0.09 \%)$ and the lower particle concentrations $\left(159 \mathrm{~cm}^{-3}\right)$ on 16 July (see Table 6). While there is uncertainty in using the maximum supersaturation calculated from the measured average $\mathrm{CDN}$ and the CCN spectra, the calculated updraft velocities were consistent with the measured mean and maximum updraft velocities (in cloud) of 0.12 and $0.94 \mathrm{~m} \mathrm{~s}^{-1}$ on 16 July and 0.32 and $1.2 \mathrm{~m} \mathrm{~s}^{-1}$ on 10 August, respectively. It is interesting to note that the number of below cloud accumulation particles measured by the passive cavity aerosol spectrometer probe (PCASP; $148 \mathrm{~cm}^{-3}$ ) is very close to the droplet number $\left(156 \mathrm{~cm}^{-3}\right)$ on 10 August, similar to a broad range of marine stratocumulus observations (Hegg et al. 2012), but not on 16 July-perhaps suggesting that the weak updrafts and $0.09 \%$ supersaturation are not frequently present.

Several interesting questions arise: Why did the cargo ship droplets not grow as large as those from the smoke? Was it simply because they started out smaller and did not catch up, despite the presence of soluble sulfate ions? Also, why were the background droplet concentrations so different on these two days? Was it because of their lower particle concentrations, differences in meteorology, or both?

We can address these questions with an ACP model, which is designed for tracking the detailed
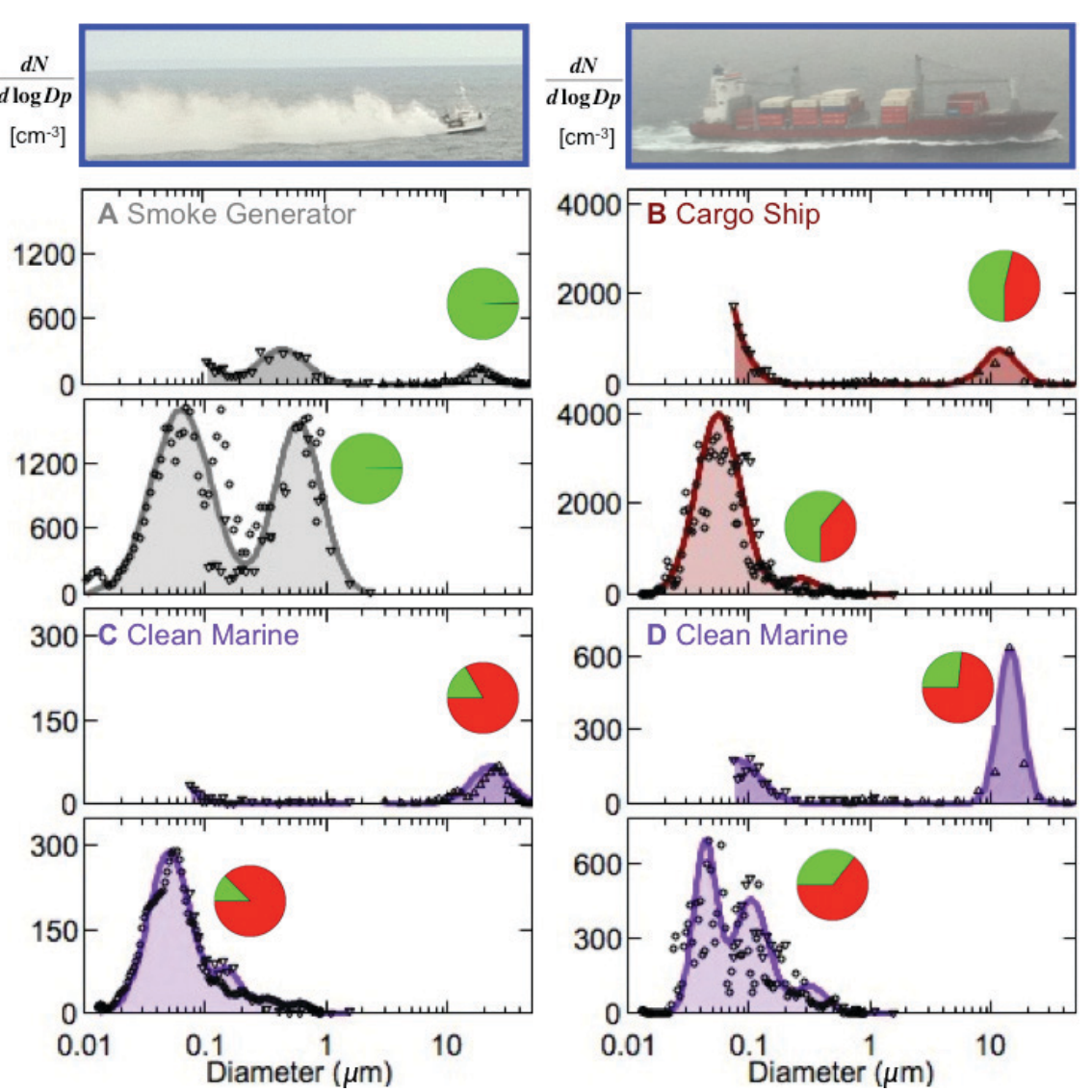

Fig. 6. Examples of particle and droplet number distributions and mass-based nonrefractory chemical composition, from measurements (bottom) below and (top) in cloud, for the (a) smoke generator on the R/V Point Sur on 16 Jul (gray) and for the (b) stack emissions of a cargo ship on 10 Aug (maroon). The background particle and droplet concentrations are shown for (c) $16 \mathrm{Jul}$ and (d) 10 Aug (purple). The size distributions are plotted at the measured relative humidity and wet for supermicron droplets in cloud $[\triangle: 3<$ CDP $<50 \mu \mathrm{m}$ for $16 \mathrm{Jul}$ and I < cloud aerosol spectrometer (CAS) < $50 \mu \mathrm{m}$ for $10 \mathrm{Aug}$ ], with passive heating for submicron particles in (interstitial) and below cloud ( $\nabla: 0.1<$ PCASP $<2 \mu \mathrm{m}$ ), and dried below cloud (O: $0.01<$ scanning DMA $<0.9 \mu \mathrm{m})$. The pies show composition of the droplets in cloud measured by AMS for (bottom) submicron particles below cloud and for (top) the residuals of cloud droplets that are left after drying in a CVI (II $\mu \mathrm{m}<\mathrm{CVI})$, with colors the same as for Fig. 3 (green-organic components; red-sulfate). Refractory chemical components (such as sea salt) were not measured behind the CVI and are not included in the pie graphs. The measurements were collected on the CIRPAS Twin Otter on 10 Aug for the cargo ship (165I-183I LT) and 16 Jul for the smoke generators (1704-180I LT).

microphysical interactions of particles with different chemical composition in clouds under specified thermodynamic conditions (Russell and Seinfeld 1998). Here, we can use the model to track the interactions of chemically different particle populations to isolate the increases in cloud drop number concentration to specific sources, such as ship tracks. For example, Russell et al. (1999) showed that droplet number is predicted to be strongly dependent on the concentration and composition of submicron 
aerosol particles. More recently, this model was used to analyze the role of organic particles in producing drop distributions in fog (Ming and Russell 2004), making it well suited for looking at smoke particles. The model's key computational features are a twomoment method for aerosol dynamics (both number and mass are tracked separately) and an adjustable framework for incorporating chemical properties (we choose how many different particle types to include). By simulating the step-by-step process of particle activation to droplets and growth beyond that, the model lets us address important questions, such as the role of supersaturation fluctuations from turbulence (e.g., Feingold et al. 1998) and kinetic inhibitions from reduced accommodation of water vapor onto growing droplets in marine stratocumulus in this region (e.g., Ruehl et al. 2009). It is also important to acknowledge that numerous studies have used similar models to understand some of the complex interactions of other types of cloud systems, such as pyroconvective clouds (Reutter et al. 2009).

The novel aspect of using E-PEACE observations for ACP studies is that we can constrain the starting point with the particle number, size, and composition of emitted particles, predict their activation in cloud by constraining them to a maximum supersaturation calculated from the measured CCN spectra (Table 6), and then compare the extent to which the prediction of the initial cloud droplet growth in the first updraft matches in-cloud observations. The differences in the cloud properties for the two days and different particle types also show that our question of why the background cloud droplets on the two days are so different has several answers-it is both the larger number and larger size of aerosol particles $\left(148 \mathrm{~cm}^{-3}\right.$ in the accumulation mode) on 10 August and the higher updraft velocities needed to give supersaturations of $0.19 \%$ rather than $0.09 \%$ on 16 July. Exploring the reasons behind these differences with ACP simulations is the topic of a forthcoming paper.

\section{CLOUD DEEPENING BY PARTICLES. In} addition to microphysical ACP modeling studies, parallel progress has been made by investigating the complexities of the convective structure of marine boundary layers using LES models constrained by observations, as summarized in Table 2. Investigations from recent LES studies have tackled numerical issues, such as spatial resolution (Hill et al. 2009) and complex feedbacks between cloud droplet distributions and LWP (Ackerman et al. 2003), between relative dispersion and albedo changes ( $\mathrm{Lu}$ and Seinfeld 2006), between vertical stratification and LWP (Sandu et al. 2009), and between drizzle and LWP

\section{GIANT CCN STRATOCUMULUS CLOUD SEEDING}

$\mathrm{T}$ he role of GCCN in stimulating precipitation production in stratocumulus clouds suggested by Woodcock (1950) has been studied recently using LES and parcel models (e.g., Feingold et al. 1999; Jensen and Lee 2008). These studies indicate that GCCN introduced into nonprecipitating stratocumulus clouds can promote the growth of droplets to drizzle by acting as collector drops with higher rates of collision and coalescence. Nevertheless, observing the effects of GCCN in real clouds is challenging. First, GCCN concentrations in nature $\left(10^{-4}-10^{-2} \mathrm{~cm}^{-3}\right)$ are many orders of magnitude less than $\mathrm{CCN}\left(10^{2} \mathrm{~cm}^{-3}\right)$ and thus difficult to measure from an aircraft. Second, since factors other than GCCN injection can affect and modulate drizzle production, it is difficult to establish cause and effect. In principle, marine stratocumulus clouds present laboratory-like conditions for directly evaluating how added GCCN can modify the cloud properties. By introducing GCCN directly into an unbroken and well-developed cloud, the properties of the seeded cloud region can be compared with the unperturbed background cloud conditions.

Techniques for artificially seeding clouds with GCCN have been developed for the deliberate enhancement of precipitation in warm cumulus clouds. One technique that has been reported for cloud perturbation is airborne flares that produce a wide spectrum of hygroscopic particles with a tail of larger particles that serve as GCCN (Ghate et al. 2007). To artificially introduce GCCN without increasing the smaller CCN, we employ a technique developed by Rosenfeld et al. (2010) that uses milled salt particles (in the range of 3-5- $\mu$ m diameter) that are mixed with $\mathrm{SiO}_{2}$ to prevent sticking and clumping of the particles. In E-PEACE we injected salt powder (provided by D. Rosenfeld) from the CIRPAS Twin Otter into the cloud. To deliver these particles, we designed and fabricated an apparatus that used an auger to feed the salt powder into a fluidized bed of grit maintained by air pumped into the grit chamber that then ejects the powder into the aircraft's airflow, where it is dispersed. The injection rate of salt mass from the aircraft is designed to produce GCCN concentrations in the environment of the order of $10^{-3} \mathrm{~cm}^{-3}$. After the GCCN are dispersed into the cloud, the aircraft returns to sample the moving cloudy air mass into which the particles were injected. Airborne frequency-modulated continuous wave cloud radar is especially advantageous in measuring the response of the seeded region in the cloud. Since the radar has a very shallow dead zone (less than $50 \mathrm{~m}$ ), the reflectivity from the radar returns closest to the aircraft can be compared directly with the in situ aircraft probe observations. 
(Caldwell and Bretherton 2009; Jiang et al. 2010). These basic feedbacks can be captured in some cases by simpler mixed-layer models (Wood et al. 2009). While many of these studies focus on the changes in boundary layers that occur during the course of a day, Savic-Jovcic and Stevens (2008) have also explored the nighttime marine boundary layer.

We have used large-eddy simulations to represent microphysics and dynamics of marine stratocumulus. A detailed bin-resolved microphysical scheme is employed in the Weather Research and Forecasting (WRF) model running in the LES mode (Chen et al. 2011). In the bin microphysical scheme, aerosol number, cloud drop mass, and cloud drop number are computed over a size-resolved spectrum, predicting both cloud drop mass and number concentration following the moment-conserving technique (Reisin et al. 1996; Tzivion et al. 1987, 1989). The microphysical processes include aerosol activation, drop condensation/evaporation, collision-coalescence, collisional breakup, and sedimentation. The impacts of ship plume and giant sea salt injection enable us to understand how different aerosol sizes, chemical compositions, and emitted locations affect the cloud dynamics.

Measurements on the CIRPAS aircraft show that cloud depth is an important feature of clouds that is affected by particles. As an example, on 4 and
10 August we conducted spiral soundings in an area influenced by large tanker ship emissions immediately adjacent to areas of background marine air. We used a cutoff of $0.05 \mathrm{~g} \mathrm{~m}^{-3}$ of liquid water to identify the top and bottom of the cloud. On 4 August, the cloud region was thicker in the track from the cargo ship, consistent with the hypothesis of Ackerman et al. (2004). However, on 10 August, almost no difference was seen in the clean and polluted areas; in fact, the cloud in the track may have actually been somewhat thinner, contrary to what we expect for indirect effects. GOES images (Fig. 4) taken during the times when the Twin Otter was present show some differences in cloud structure, which may offer clues about these different results.

\section{PRECIPITATION EFFECTS OF GIANT}

PARTICLES. The pioneering work on the effects of giant particles on precipitation is summarized in "Giant CCN stratocumulus cloud seeding." Recently, L'Ecuyer et al. (2009) showed that injection of sea salt and sulfate aerosols led to nearly opposite cloud responses. Addition of large sea salt particles enhances precipitation and leads to less vertically developed clouds. However, addition of the considerably smaller sulfate particles suppresses precipitation in clouds and results in the onset of light precipitation at higher LWPs. Also, air masses from

\begin{tabular}{|c|c|c|c|c|}
\hline \multirow{2}{*}{$\begin{array}{l}\text { Date of measurement } \\
\text { Description of particles }\end{array}$} & \multicolumn{2}{|c|}{$16 \mathrm{Jul}$} & \multicolumn{2}{|c|}{10 Aug } \\
\hline & Background & Generator smoke & Background & Cargo ship \\
\hline Cloud-base height (m) & 145 & 145 & 338 & 338 \\
\hline Cloud-top height (m) & 370 & 370 & 670 & 670 \\
\hline Below cloud particles (CPC) $\left(\mathrm{cm}^{-3}\right)$ & 159 & 1,786 & 361 & 1,938 \\
\hline Below cloud accumulation particles (PCASP) $\left(\mathrm{cm}^{-3}\right)$ & 46 & 659 & 148 & 644 \\
\hline Calculated maximum supersaturation ${ }^{\mathrm{a}}(\mathrm{CCN})(\%)$ & 0.09 & 0.09 & 0.25 & 0.25 \\
\hline Calculated activation diameter ${ }^{\mathrm{b}}(\mu \mathrm{m})$ & 0.13 & I.I & 0.06 & 0.09 \\
\hline In-cloud mean/max positive updraft velocity $\left(\mathrm{m} \mathrm{s}^{-1}\right)$ & \multicolumn{2}{|c|}{$0.12 / 0.94$} & \multicolumn{2}{|c|}{$0.32 / 1.2$} \\
\hline In-cloud mean/std dev of all updraft velocity $\left(\mathrm{m} \mathrm{s}^{-1}\right)$ & \multicolumn{2}{|c|}{$-0.09 / 0.22$} & \multicolumn{2}{|c|}{$+0.13 / 0.39$} \\
\hline In-cloud accumulation particles (PCASP) $\left(\mathrm{cm}^{-3}\right)$ & 3 & 188 & 49 & 214 \\
\hline In-cloud droplet number (CAS, CDP) $\left(\mathrm{cm}^{-3}\right)$ & 25 & 49 & 156 & 277 \\
\hline In-cloud droplet diameter ${ }^{d}(\mathrm{CAS}, \mathrm{CDP})(\mu \mathrm{m})$ & 26.5 & 18.6 & 14.3 & 11.8 \\
\hline
\end{tabular}

a The supersaturation is calculated from the CCN spectrum as the supersaturation at which the measured CDN is equal to the CCN, interpolated between measured supersaturation using sigmoidal fit $( \pm 0.04 \%)$.

${ }^{b}$ The activation diameter is calculated as the size of the smallest particle needed to activate to produce the measured CDN, assuming all larger particles activated.

c The in-cloud updraft velocity is calculated from I- $\mathrm{Hz}$ measurements during 30 -min sampling legs in cloud at $220 \mathrm{~m}$ for $16 \mathrm{Jul}$ and $480 \mathrm{~m}$ for 10 Aug; the same value is used for both background and track, since sampling was insufficient to identify updraft rates in tracks.

${ }^{d}$ Cloud droplet diameters are reported at the peak concentration of the droplet mode. 
different source regions may produce different effects on clouds (Su et al. 2010), as those originating above polluted continental areas will have a different physicochemical signature than those from remote ocean regions (Hersey et al. 2009; Sorooshian et al. 2009a).

To study the effects of giant CCN (GCCN) on precipitation (see "Giant CCN stratocumulus cloud seeding"), we released the third type of emitted particle (3-5- $\mu \mathrm{m}$-diameter milled salt particles) from the aircraft while flying just above cloud base. Nine flights included GCCN seeding, within which three cases (9 July, and 3 and 11 August) revealed enhanced precipitation after seeding (others were characterized by insufficient data, inadequate sampling, or a similar drizzle rate after seeding). In these three seeding cases, GCCN were released crosswind at a constant altitude (below cloud top, or midcloud) in unbroken clouds. The air mass seeded was then sampled downstream, where signatures of enhanced drizzle were observed by the optical probes and the upward-facing radar mounted on the Twin Otter. However, it was found to be challenging to confirm the sampled air mass was the same as that into which the salt was injected. To confirm that the downwind sampling occurred within the seeded region, during the research flight on 11 August, black carbon particles were mixed with the salt to serve as a tracer. Though enhanced precipitation was observed after seeding, the black carbon concentration detected by the single-particle soot photometer (SP2) within the sampling region was similar to its background concentration, and thus it did not provide unequivocal evidence of sampling of the region into which GCCN was injected.
In these three cases, the seeded clouds were clean (with low cloud droplet number concentration) and already drizzling prior to seeding. Previous modeling studies (e.g., Feingold et al. 1999) suggest that injection of GCCN has the greatest potential for altering cloud behavior when CCN concentrations are already relatively high, so that conditions during these three cases were not optimal for generating a strong precipitation signal. Based on the analysis of these three cases, robust evidence of precipitation enhancement from GCCN seeding was lacking. The difficulty in tracking the moving cloudy air mass within which GCCN were injected by an aircraft underscores the challenge associated with such in situ cloud perturbation experiments.

SUMMARY AND OUTLOOK. The campaign of the Eastern Pacific Emitted Aerosol Cloud Experiment (E-PEACE) was designed to take advantage of recent advances in both instruments and models used to collect detailed, quantitative observations of the effects of particles on clouds. Using innovative new particle emission and measurement technologies, three kinds of particles were emitted and controlled, each as a single variable in the highly complex, natural system governing marine stratocumulus clouds. Since the emitted particles span $100 \mathrm{~nm}$ to several micrometers in diameter, the E-PEACE observations cover a wide range of cloud droplet sizes and number concentrations. The outcome of these studies revealed that both incidental smoke and ship emissions are effective at modifying cloud albedo, as well as that giant salt nuclei can increase drizzle

\section{COOLING EFFICIENCY OF CARGO SHIPS AND SMOKE}

C moke emissions from smoke generators were employed $J_{\text {in the present study, along with the incidental emissions }}$ of transoceanic cargo ships (Conover 1969; Durkee et al. 2000c). Here we consider the extent to which each of these two types of oceangoing particle emissions provides a net cooling effect (based only on fuel consumed, not emissions from ship construction).

Take into consideration a single day for both smoke and cargo ship emissions in clouds that form tracks, an average summertime lifetime of the track in the cloud of $6 \mathrm{~h}$ (normalized to a $100-y r$ time horizon), and an average daily fuel consumption at typical transit speeds. We calculate the asymptotic $\mathrm{CO}_{2}$-caused temperature increase from $3 \mathrm{~K}$ per 280 ppmv (Solomon et al. 2007) and find I nK ( $10^{-9} \mathrm{~K}$ ) from the 100,000-gal bunker fuel burned by the cargo ship and $0.008 \mathrm{nK}$ for the 500 -gal marine diesel burned by the R/V Point Sur. The cargo ship typically transits 5 times faster than the R/V Point Sur, so the area covered by the track (as- suming the same wind speed in the lateral direction) is taken to be 5 times larger, providing $2,500 \mathrm{~km}^{2}$ for the cargo ship and $500 \mathrm{~km}^{2}$ for the smoke. We use the $15 \%$ cloud brightening measured for the smoke on 16 July (Fig. 5) for both tracks to find 2-nK cooling for the cargo ship and 0.4-nK cooling for the smoke - that gives us ratios of cooling to warming (i.e., a cooling efficiency) of $\sim 2$ for the cargo ship and $\sim 50$ for the smoke generator.

Although this is a very simplified calculation, we find that, if half of the open-ocean transit days of a cargo ship result in tracks that are on average 15\% brighter than the surrounding clouds and cover $2,500 \mathrm{~km}^{2}$, then cargo ship transit (for consumables only) could be considered "carbon neutral" (in the sense of having no net warming effect) transportation. Further, we find that smoke generators on board smaller ships (that require less than $2 \%$ of the fuel per transit mile) could provide a net cooling effect, which could be used to offset some of the warming caused by ship $\mathrm{CO}_{2}$ emissions. 
rates. The multiple particle sizes provide constraints for both ACP and LES models, allowing us to carry out future modeling simulations to place the observations in a theoretical framework that can be extended to global models. When considering these results in the context of Earth's solar radiation balance and the relative amounts of cooling and warming produced by different particle emissions (see "Cooling efficiency of cargo ships and smoke"), we suggest that the effective carbon offsets from cloud tracks from cargo ships should be considered. Clearly such considerations would need to extend beyond the local aerosol-cloud-radiation interactions assessed here to the effects of tracks on neighboring clouds as well as ecosystem impacts.

ACKNOWLEDGMENTS. The E-PEACE field campaign and modeling studies were funded by the National Science Foundation (Grants AGS-1013423, AGS-1008848, AGS-1013381, AGS-1013319; ATM-0744636, AGS-0821599, and ATM-0349015) and the Office of Naval Research (Grants N00014-11-1-0783, N00014-10-1-0811, N00014-101-0200, and N00014-08-1-0465). Sea Spray Research, Inc. provided oil for the operation of the smoke generators. The authors gratefully acknowledge the crews of the CIRPAS Twin Otter and the R/V Point Sur for their assistance during the field campaign; Tom Maggard, who revived and tirelessly maintained the smoke generators during the cruise; David Malmberg and the crew of the R/V Sproul, for their assistance in testing the smoke generators prior to the campaign; Spyros Pandis, for providing the CCN spectrometer; and Daniel Rosenfeld, for providing the powdered salt. We also thank Richard Leaitch and two anonymous reviewers for providing helpful comments on the submitted manuscript.

\section{REFERENCES}

Ackerman, A. S., O. B. Toon, D. E. Stevens, and J. A. Coakley Jr., 2003: Enhancement of cloud cover and suppression of nocturnal drizzle in stratocumulus polluted by haze. Geophys. Res. Lett., 30, 1381, doi:10.1029/2002gl016634.

—, M. P. Kirkpatrick, D. E. Stevens, and O. B. Toon, 2004: The impact of humidity above stratiform clouds on indirect aerosol climate forcing. Nature, 432, 1014-1017, doi:10.1038/nature03174.

Albrecht, B. A., 1989: Aerosols, cloud microphysics, and fractional cloudiness. Science, 245, 1227-1230.

Allen, G., and Coauthors, 2011: South east Pacific atmospheric composition and variability sampled along $20^{\circ} \mathrm{S}$ during VOCALS-REx. Atmos. Chem. Phys., 11, 5237-5262, doi:10.5194/acp-11-5237-2011.
Barkstrom, B. R., 1984: The Earth Radiation Budget Experiment (ERBE). Bull. Amer. Meteor. Soc., 65, 1170-1185.

Brenguier, J. L., H. Pawlowska, L. Schuller, R. Preusker, J. Fischer, and Y. Fouquart, 2000: Radiative properties of boundary layer clouds: Droplet effective radius versus number concentration. J. Atmos. Sci., 57, 803-821.

Bretherton, C. S., R. Wood, R. C. George, D. Leon, G. Allen, and X. Zheng, 2010: Southeast Pacific stratocumulus clouds, precipitation and boundary layer structure sampled along $20^{\circ} \mathrm{S}$ during VOCALS-REx. Atmos. Chem. Phys., 10, 10 639-10 654, doi:10.5194/ acp-10-10639-2010.

Caldwell, P., and C. S. Bretherton, 2009: Response of a subtropical stratocumulus-capped mixed layer to climate and aerosol changes. J. Climate, 22, 20-38.

Chen, Y.-C., L. Xue, Z. J. Lebo, H. Wang, R. M. Rasmussen, and J. H. Seinfeld, 2011: A comprehensive numerical study of aerosol-cloud-precipitation interactions in marine stratocumulus. Atmos. Chem. Phys., 11, 9749-9769, doi:10.5194/acp-11-9749-2011.

—, M. W. Christensen, L. Xue, A. Sorooshian, G. L. Stephens, R. M. Rasmussen, and J. H. Seinfeld, 2012: Occurrence of lower cloud albedo in ship tracks. Atmos. Chem. Phys. Discuss., 12, $13553-13$ 580, doi: 10.5194/acpd-12-13553-2012.

Christensen, M. W., and G. L. Stephens, 2011: Microphysical and macrophysical responses of marine stratocumulus polluted by underlying ships: Evidence of cloud deepening. J. Geophys. Res., 116, D03201, doi:10.1029/2010jd014638.

Coakley, J. A., and C. D. Walsh, 2002: Limits to the aerosol indirect radiative effect derived from observations of ship tracks. J. Atmos. Sci., 59, 668-680.

— , R. L. Bernstein, and P. A. Durkee, 1987: Effect of ship-stack effluents on cloud reflectivity. Science, 237, 1020-1022.

— , and Coauthors, 2000: The appearance and disappearance of ship tracks on large spatial scales. J. Atmos. Sci., 57, 2765-2778.

Coggon, M. M., and Coauthors, 2012: Ship impacts on the marine atmosphere: Insights into the contribution of shipping emissions to the properties of marine aerosol and clouds. Atmos. Chem. Phys. Discuss., 12, 14393-14445, doi:10.5194/acpd-12-14393-2012.

Conover, J. H., 1966: Anomalous cloud lines. J. Atmos. Sci., 23, 778-785.

— 1969: New observations of anomalous cloud lines. J. Atmos. Sci., 26, 1153-1154.

Crahan, K. K., D. A. Hegg, D. S. Covert, H. Jonsson, J. S. Reid, D. Khelif, and B. J. Brooks, 2004: Speciation of organic aerosols in the tropical mid-Pacific and 
their relationship to light scattering. J. Atmos. Sci., 61, 2544-2558.

Curry, J. A., E. E. Ebert, and G. F. Herman, 1988: Mean and turbulence structure of the summertime Arctic cloudy boundary layer. Quart. J. Roy. Meteor. Soc., 114, 715-746.

Drofa, A. S., V. N. Ivanov, D. Rosenfeld, and A. G. Shilin, 2010: Studying an effect of salt powder seeding used for precipitation enhancement from convective clouds. Atmos. Chem. Phys., 10, 8011-8023, doi:10.5194/acp-10-8011-2010.

Durkee, P. A., and Coauthors, 2000a: Composite ship track characteristics. J. Atmos. Sci., 57, 2542-2553.

— , and Coauthors, 2000b: The impact of ship-produced aerosols on the microstructure and albedo of warm marine stratocumulus clouds: A test of MAST hypotheses 1i and 1ii. J. Atmos. Sci., 57, 2554-2569.

— , K. J. Noone, and R. T. Bluth, 2000c: The Monterey Area Ship Track Experiment. J. Atmos. Sci., 57, 2523-2541.

Faloona, I., and Coauthors, 2005: Observations of entrainment in eastern Pacific marine stratocumulus using three conserved scalars. J. Atmos. Sci., 62, 3268-3285.

Feingold, G., and H. Siebert, 2009: Cloud-aerosol interactions from the micro to the cloud scale. Clouds in the Perturbed Climate System: Their Relationship to Energy Balance, Atmospheric Dynamics, and Precipitation, J. Heintzenberg and R. J. Charlson, Eds., MIT Press, 319-338.

— , S. M. Kreidenweis, and Y. Zhang, 1998: Stratocumulus processing of gases and cloud condensation nuclei: 1. Trajectory ensemble model. J. Geophys. Res., 103 (D16), 19527-19542.

—, W. R. Cotton, S. M. Kreidenweis, and J. T. Davis, 1999: The impact of giant cloud condensation nuclei on drizzle formation in stratocumulus: Implications for cloud radiative properties. J. Atmos. Sci., 56, 4100-4117.

—, R. Furrer, P. Pilewskie, L. A. Remer, Q. L. Min, and H. Jonsson, 2006: Aerosol indirect effect studies at Southern Great Plains during the May 2003 intensive operations period. J. Geophys. Res., 111, D05S14, doi:10.1029/2004jd005648.

—, I. Koren, H. L. Wang, H. W. Xue, and W. A. Brewer, 2010: Precipitation-generated oscillations in open cellular cloud fields. Nature, 466, 849-852, doi:10.1038/nature09314.

Ferek, R. J., D. A. Hegg, P. V. Hobbs, P. Durkee, and K. Nielsen, 1998: Measurements of ship-induced tracks in clouds off the Washington coast. J. Geophys. Res., 103 (D18), 23 199-23206.

— , and Coauthors, 2000: Drizzle suppression in ship tracks. J. Atmos. Sci., 57, 2707-2728.
Frick, G. M., and W. A. Hoppel, 2000: Airship measurements of ship's exhaust plumes and their effect on marine boundary layer clouds. J. Atmos. Sci., 57, 2625-2648.

Ghate, V. P., B. A. Albrecht, P. Kollias, H. H. Jonsson, and D. W. Breed, 2007: Cloud seeding as a technique for studying aerosol-cloud interactions in marine stratocumulus. Geophys. Res. Lett., 34, L14807, doi:10.1029/2007gl029748.

Hawkins, L. N., L. M. Russell, C. H. Twohy, and J. R. Anderson, 2008: Uniform particle-droplet partitioning of 18 organic and elemental components measured in and below DYCOMS-II stratocumulus clouds. J. Geophys. Res., 113, D14201, doi:10.1029/2007jd009150.

Hegg, D. A., and P. V. Hobbs, 1986: Sulfate and nitrate chemistry in cumuliform clouds. Atmos. Environ., 20, 901-909.

- D. S. Covert, and H. H. Jonsson, 2008: Measurements of size-resolved hygroscopicity in the California coastal zone. Atmos. Chem. Phys., 8, 7193-7203.


natural and anthropogenic cloud condensation nuclei in the California coastal zone. Tellus, 61B, 669-676, doi:10.1111/j.1600-0889.2009.00435.x.

$-, \ldots, \ldots$, and —_ 2012: A simple relationship between cloud drop number concentration and precursor aerosol concentration for the regions of Earth's large marine stratocumulus decks. Atmos. Chem. Phys., 12, 1229-1238, doi:10.5194/acp-121229-2012.

Hersey, S. P., A. Sorooshian, S. M. Murphy, R. C. Flagan, and J. H. Seinfeld, 2009: Aerosol hygroscopicity in the marine atmosphere: A closure study using high-time-resolution, multiple-RH DASH-SP and size-resolved C-ToF-AMS data. Atmos. Chem. Phys., 9, 2543-2554.

Hill, A. A., G. Feingold, and H. L. Jiang, 2009: The influence of entrainment and mixing assumption on aerosol-cloud interactions in marine stratocumulus. J. Atmos. Sci., 66, 1450-1464.

Hobbs, P. V., and Coauthors, 2000: Emissions from ships with respect to their effects on clouds. J. Atmos. Sci., 57, 2570-2590.

Hsieh, W. C., A. Nenes, R. C. Flagan, J. H. Seinfeld, G. Buzorius, and H. Jonsson, 2009: Parameterization of cloud droplet size distributions: Comparison with parcel models and observations. J. Geophys. Res., 114, D11205, doi:10.1029/2008jd011387.

Jensen, J. B., and S. Lee, 2008: Giant sea-salt aerosols and warm rain formation in marine stratocumulus. J. Atmos. Sci., 65, 3678-3694. 
Jiang, H. L., G. Feingold, and A. Sorooshian, 2010: Effect of aerosol on the susceptibility and efficiency of precipitation in warm trade cumulus clouds. J. Atmos. Sci., 67, 3525-3540.

Klein, S. A., and D. L. Hartmann, 1993: The seasonal cycle of low stratiform clouds. J. Climate, 6, 1587-1606.

L'Ecuyer, T. S., W. Berg, J. Haynes, M. Lebsock, and T. Takemura, 2009: Global observations of aerosol impacts on precipitation occurrence in warm maritime clouds. J. Geophys. Res., 114, D09211, doi:10.1029/2008jd011273.

Lance, S., C. A. Brock, D. Rogers, and J. A. Gordon, 2010: Water droplet calibration of the cloud droplet probe (CDP) and in-flight performance in liquid, ice and mixed-phase clouds during ARCPAC. Atmos. Meas. Tech., 3, 1683-1706, doi:10.5194/amt-3-1683-2010.

Lilly, D. K., 1968: Models of cloud-topped mixed layers under a strong inversion. Quart. J. Roy. Meteor. Soc., 94, 292-309.

Lu, M.-L., and J. H. Seinfeld, 2005: Study of the aerosol indirect effect by large-eddy simulation of marine stratocumulus. J. Atmos. Sci., 62, 3909-3932.

—, and —, 2006: Effect of aerosol number concentration on cloud droplet dispersion: A largeeddy simulation study and implications for aerosol indirect forcing. J. Geophys. Res., 111, D02207, doi:10.1029/2005jd006419.

—, W. C. Conant, H. H. Jonsson, V. Varutbangkul, R. C. Flagan, and J. H. Seinfeld, 2007: The Marine Stratus/ Stratocumulus Experiment (MASE): Aerosol-cloud relationships in marine stratocumulus. J. Geophys. Res., 112, D10209, doi:10.1029/2006jd007985.

—, A. Sorooshian, H. H. Jonsson, G. Feingold, R. C. Flagan, and J. H. Seinfeld, 2009: Marine stratocumulus aerosol-cloud relationships in the MASE-II experiment: Precipitation susceptibility in eastern Pacific marine stratocumulus. J. Geophys. Res., 114, D24203, doi:10.1029/2009jd012774.

Meskhidze, N., A. Nenes, W. C. Conant, and J. H. Seinfeld, 2005: Evaluation of a new cloud droplet activation parameterization with in situ data from CRYSTAL-FACE and CSTRIPE. J. Geophys. Res., 110, D16202, doi:10.1029/2004jd005703.

Ming, Y., and L. M. Russell, 2004: Organic aerosol effects on fog droplet spectra. J. Geophys. Res., 109, D10206, doi:10.1029/2003jd004427.

Moore, R. H., and A. Nenes, 2009: Scanning flow CCN analysis-A method for fast measurements of CCN spectra. Aerosol Sci. Technol., 43, 1192-1207, doi:10.1080/02786820903289780.

Noone, K. J., and Coauthors, 2000a: A case study of ship track formation in a polluted marine boundary layer. J. Atmos. Sci., 57, 2748-2764.
—-, and Coauthors, 2000b: A case study of ships forming and not forming tracks in moderately polluted clouds. J. Atmos. Sci., 57, 2729-2747.

Petters, M. D., J. R. Snider, B. Stevens, G. Vali, I. Faloona, and L. M. Russell, 2006: Accumulation mode aerosol, pockets of open cells, and particle nucleation in the remote subtropical Pacific marine boundary layer. J. Geophys. Res., 111, D02206, doi:10.1029/2004jd005694.

Platnick, S., and Coauthors, 2000: The role of background cloud microphysics in the radiative formation of ship tracks. J. Atmos. Sci., 57, 2607-2624.

Radke, L. F., J. A. Coakley Jr., and M. D. King, 1989: Direct and remote sensing observations of the effects of ships on clouds. Science, 246, 1146-1149.

Reisin, T., Z. Levin, and S. Tzivion, 1996: Rain production in convective clouds as simulated in an axisymmetric model with detailed microphysics. Part I: Description of the model. J. Atmos. Sci., 53, 497-519.

Reutter, P., and Coauthors, 2009: Aerosol- and updraftlimited regimes of cloud droplet formation: Influence of particle number, size and hygroscopicity on the activation of cloud condensation nuclei (CCN). Atmos. Chem. Phys., 9, 7067-7080.

Roberts, G. C., and A. Nenes, 2005: A continuous-flow streamwise thermal-gradient CCN chamber for atmospheric measurements. Aerosol Sci. Technol., 39, 206-221, doi:10.1080/027868290913988.

-, M. V. Ramana, C. Corrigan, D. Kim, and V. Ramanathan, 2008: Simultaneous observations of aerosol-cloud-albedo interactions with three stacked unmanned aerial vehicles. Proc. Natl. Acad. Sci. USA, 105, 7370-7375, doi:10.1073/pnas.0710308105.

Rosenfeld, D., D. Axisa, W. L. Woodley, and R. Lahav, 2010: A quest for effective hygroscopic cloud seeding. J. Appl. Meteor. Climatol., 49, 1548-1562.

Ruehl, C. R., P. Y. Chuang, and A. Nenes, 2009: Distinct $\mathrm{CCN}$ activation kinetics above the marine boundary layer along the California coast. Geophys. Res. Lett., 36, L15814, doi:10.1029/2009gl038839.

Russell, L. M., and J. H. Seinfeld, 1998: Size- and composition-resolved externally mixed aerosol model. Aerosol Sci. Technol., 28, 403-416.

_- and Coauthors, 1999: Aerosol dynamics in ship tracks. J. Geophys. Res., 104 (D24), 31 077-31 095.

Sandu, I., J. L. Brenguier, O. Thouron, and B. Stevens, 2009: How important is the vertical structure for the representation of aerosol impacts on the diurnal cycle of marine stratocumulus? Atmos. Chem. Phys., 9, 4039-4052.

Savic-Jovcic, V., and B. Stevens, 2008: The structure and mesoscale organization of precipitating stratocumulus. J. Atmos Sci., 65, 1587-1605. 
Schreier, M., H. Mannstein, V. Eyring, and H. Bovensmann, 2007: Global ship track distribution and radiative forcing from 1 year of AATSR data. Geophys.Res. Lett., 34, L17814, doi:10.1029/2007gl030664.

Schubert, W. H., J. S. Wakefield, E. J. Steiner, and S. K. Cox, 1979a: Marine stratocumulus convection. Part I: Governing equations and horizontally homogeneous solutions. J. Atmos. Sci., 36, 1286-1307.

$-, \ldots, \ldots$, and $\_, 1979 \mathrm{~b}$ : Marine stratocumulus convection. Part II: Horizontally inhomogeneous solutions. J. Atmos. Sci., 36, 1308-1324.

Scorer, R. S., 1987: Ship trails. Atmos. Environ., 21, 1417-1425.

Segrin, M. S., J. A. Coakley, and W. R. Tahnk, 2007: MODIS observations of ship tracks in summertime stratus off the West Coast of the United States. J. Atmos. Sci., 64, 4330-4345.

Sharon, T. M., B. A. Albrecht, H. H. Jonsson, P. Minnis, M. M. Khaiyer, T. M. van Reken, J. Seinfeld, and R. Flagan, 2006: Aerosol and cloud microphysical characteristics of rifts and gradients in maritime stratocumulus clouds. J. Atmos. Sci., 63, 983-997.

\section{Copy}

What you're reading is more than just copy. It's also copyrighted. So before you head over to the photocopier, make sure you have permission. Contact the publisher or visit www.copyright.com.

(C) Copyright Clearance Center
Shingler, T., and Coauthors, 2012: Characterisation and airborne deployment of a new counterflow virtual impactor inlet. Atmos. Meas. Tech., 5, 1259-1269, doi:10.5194/amt-5-1259-2012.

Solomon, S., D. Qin, M. Manning, M. Marquis, K. Averyt, M. M. B. Tignor, H. L. Miller Jr., and Z. Chen, Eds., 2007: Climate Change 2007: The Physical Science Basis. Cambridge University Press, 996 pp.

Sorooshian, A., M. L. Lu, F. J. Brechtel, H. Jonsson, G. Feingold, R. C. Flagan, and J. H. Seinfeld, 2007: On the source of organic acid aerosol layers above clouds. Environ. Sci. Technol., 41, 4647-4654, doi:10.1021/ es0630442.

— biota emissions, aerosol, and maritime clouds: Airborne, ground, and satellite measurements off the coast of California. Global Biogeochem. Cycles, 23, GB4007, doi:10.1029/2009gb003464.

—, G. Feingold, M. D. Lebsock, H. L. Jiang, and G. L. Stephens, 2009b: On the precipitation susceptibility of clouds to aerosol perturbations. Geophys. Res. Lett., 36, L13803, doi:10.1029/2009gl038993.

—, J. Csavina, T. Shingler, S. Dey, F. Brechtel, E. Sáez, and E. Betterton, 2012: Hygroscopic and chemical properties of aerosols collected near a copper smelter: Implications for public and environmental health. Environ. Sci. Technol., 46, 9473-9480, doi:10.1021/ es302275k.

Stephens, G. L., and Coauthors, 2002: The CloudSat mission and the A-Train: A new dimension of spacebased observations of clouds and precipitation. Bull. Amer. Meteor. Soc., 83, 1771-1790.

Stevens, B., and Coauthors, 2003: Dynamics and chemistry of marine stratocumulus - DYCOMS-II. Bull. Amer. Meteor. Soc., 84, 579-593.

—, G. Vali, K. Comstock, R. Wood, M. C. Van Zanten, P. H. Austin, C. S. Bretherton, and D. H. Lenschow, 2005: Pockets of open cells and drizzle in marine stratocumulus. Bull. Amer. Meteor. Soc., 86, 51-57.

Su, W. Y., N. G. Loeb, K.-M. Xu, G. L. Schuster, and Z. A. Eitzen, 2010: An estimate of aerosol indirect effect from satellite measurements with concurrent meteorological analysis. J. Geophys. Res., 115, D18219, doi:10.1029/2010jd013948.

Sullivan, A. P., R. E. Peltier, C. A. Brock, J. A. de Gouw, J. S. Holloway, C. Warneke, A. G. Wollny, and R. J. Weber, 2006: Airborne measurements of carbonaceous aerosol soluble in water over northeastern United States: Method development and an investigation into water-soluble organic carbon sources. J. Geophys. Res., 111, D23S46, doi:10.1029/2006jd007072. 
Twohy, C. H., M. D. Petters, J. R. Snider, B. Stevens, W. Tahnk, M. Wetzel, L. Russell, and F. Burnet, 2005: Evaluation of the aerosol indirect effect in marine stratocumulus clouds: Droplet number, size, liquid water path, and radiative impact. J. Geophys. Res., 110, D08203, doi:10.1029/2004jd005116.

Twomey, S., 1991: Aerosols, clouds and radiation. Atmos. Environ., 25A, 2435-2442.

- , H. B. Howell, and T. A. Wojciech, 1968: Comments on anomalous cloud lines. J. Atmos. Sci., 25, 333-334.

Tzivion, S., G. Feingold, and Z. Levin, 1987: An efficient numerical solution to the stochastic collection equation. J. Atmos. Sci., 44, 3139-3149.

- __ - and Z. Levin, 1989: The evolution of raindrop spectra. Part II: Collisional collection/breakup and evaporation in a rainshaft. J. Atmos. Sci., 46, 3312-3327.

Van Zanten, M. C., and B. Stevens, 2005: Observations of the structure of heavily precipitating marine stratocumulus. J. Atmos. Sci., 62, 4327-4342.

Wang, H., G. Feingold, R. Wood, and J. Kazil, 2010: Modelling microphysical and meteorological controls on precipitation and cloud cellular structures in southeast Pacific stratocumulus. Atmos. Chem. Phys., 10, 6347-6362, doi:10.5194/acp-10-6347-2010.
Wilcox, E. M., G. Roberts, and V. Ramanathan, 2006: Influence of aerosols on the shortwave cloud radiative forcing from North Pacific oceanic clouds: Results from the Cloud Indirect Forcing Experiment (CIFEX). Geophys. Res. Lett., 33, L21804, doi:10.1029/2006gl027150.

Wood, R., T. L. Kubar, and D. L. Hartmann, 2009: Understanding the importance of microphysics and macrophysics for warm rain in marine low clouds. Part II: Heuristic models of rain formation. J. Atmos. Sci., 66, 2973-2990.

— C. S. Bretherton, D. Leon, A. D. Clarke, P. Zuidema, G. Allen, and H. Coe, 2011a: An aircraft case study of the spatial transition from closed to open mesoscale cellular convection over the southeast Pacific. Atmos. Chem. Phys., 11, 2341-2370, doi:10.5194/ acp-11-2341-2011.

— , and Coauthors, 2011b: The VAMOS Ocean-CloudAtmosphere-Land Study Regional Experiment (VOCALS-REx): Goals, platforms, and field operations. Atmos. Chem. Phys., 11, 627-654, doi:10.5194/ acp-11-627-2011.

Woodcock, A. H., 1950: Condensation nuclei and precipitation. J Meteor., 7, 161-162.

\section{NEW FROM AMS BOOKS!}

\section{" It has become clear that natural disasters are at the very center of the problem of economic and social development."

\section{Economic and Societal Impacts of Tornadoes}

KEVIN M. SIMMONS AND DANIEL SUTTER

Approximately 1,200 tornadoes touch down across the United States annually, and for almost a decade, economists Simmons and Sutter have been gathering data from sources such as NOAA and the U.S. Census to examine their economic impacts and social consequences. Their unique database has enabled this fascinating and game-changing study for meteorologists, social scientists, emergency managers, and everyone studying severe weather, policy, disaster management, or applied economics.

Featuring:

- Social science perspective of tornado impacts

- Evaluation of NWS warnings and efforts to reduce casualties

- Statistical analysis of effectiveness of warning lead time, shelters, and more 


\section{HISTORY}

Weather on the Air: A History of Broadcast Meteorology ROBERT HENSON

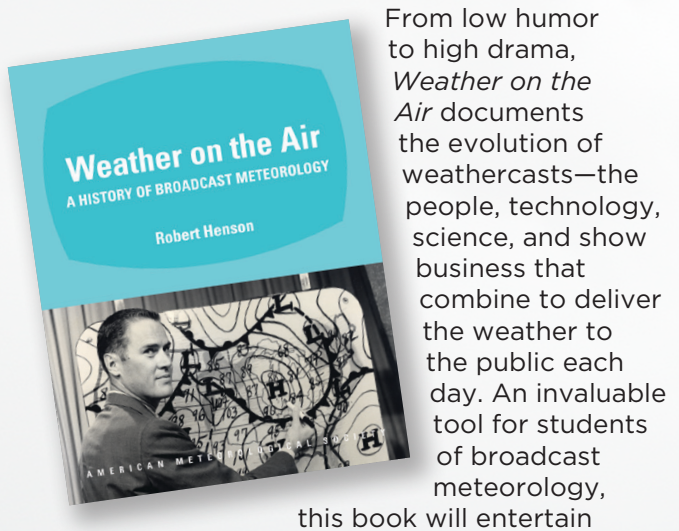

anyone fascinated by the public face of weather. Includes over 100 photographs!

C2010, HARDCOVER, 264 PAGES, ISBN 978-1-878220-98-1, AMS CODE: WOTA

LIST \$35 MEMBER \$25

\section{CLIMATE CHANGE}



\section{Adaptive Governance and Climate Change}

RONALD D. BRUNNER AND AMANDA H. LYNCH ()2010, PAPERBACK, 424 PAGES,

ISBN 978-1-878220-97-4, AMS CODE: AGCC

LIST \$35 MEMBER \$22

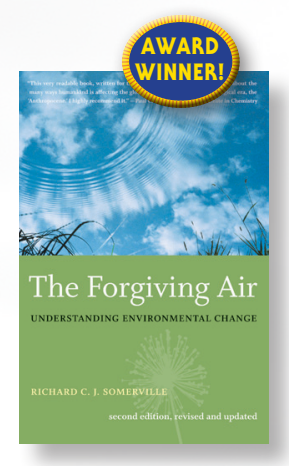

\section{The Forgiving}

Air: Understanding Environmental

Change, 2nd ed.

RICHARD C. J.

SOMERVILLE

(C)2008, PAPERBACK, 224 PAGES,

ISBN 978-1-878220-85-1, AMS CODE: TFA

LIST \$22 MEMBER \$16
ASK ABOUT THE HISTORIC ARCHIVE OF CALLENDAR'S PAPERS AVAILABLE ON DVD.

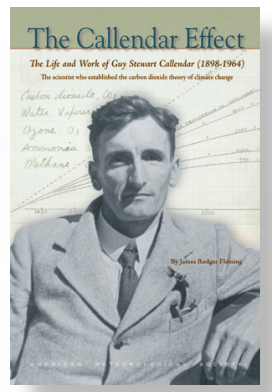

The Callendar Effect: The Life and Work of Guy Stewart Callendar (1898-1964)

JAMES RODGER FLEMING

() 2007, HARDCOVER, 176 PAGES HM, ISBN 978-1-878220-76-9, AMS CODE: CLDR

LIST \$34.95 MEMBER \$24.95

\section{CONVECTIVE PROCESSES}

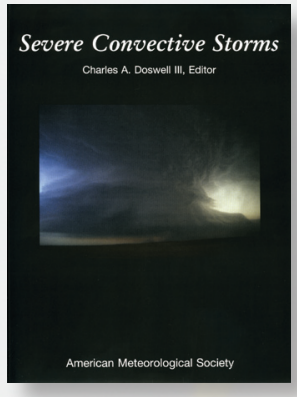

\section{Severe \\ Convective \\ Storms}

EDITED BY CHARLES

A. DOSWELL III

(c) 2001, HARDCOVER,

570 PAGES, MM

VOL. 28, NO. 50

ISBN 978-1-878220-41-7,

AMS CODE: MM50

LIST \$110 MEMBER $\$ 90$

STUDENT MEM. \$75

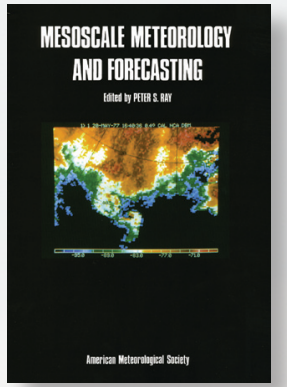

Mesoscale Meteorology and

\section{Forecasting}

EDITED BY

PETER S. RAY

(c) 1986, HARDCOVER, 793 PAGES,

ISBN 978-0-933876-66-8, AMS CODE: MESOMET

LIST \$76.25 MEMBER \$66.25 STUDENT MEM. $\$ 56.25$

\section{MIDLATITUDE WEATHER SYSTEMS}

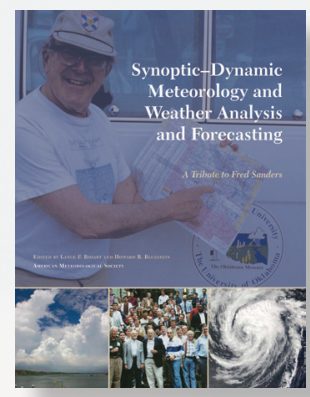

\section{Synoptic-}

Dynamic

Meteorology and Weather Analysis and Forecasting:

A Tribute to Fred

Sanders

EDITED BY LANCE F. BOSART AND HOWARD B. BLUESTEIN

(C) 2008, HARDCOVER, 440 PAGES, MM VOL. 33, NO. 55 ISBN 978-1-878220-84-4,

AMS CODE: MM55

LIST \$120 MEMBER \$80 STUDENT MEM. $\$ 60$

\section{Northeast}

VOLS, 818 PAGES, MM

VOL. 32, NO. 54, AMS CODE: MM54

STUDENT MEM. $\$ 60$
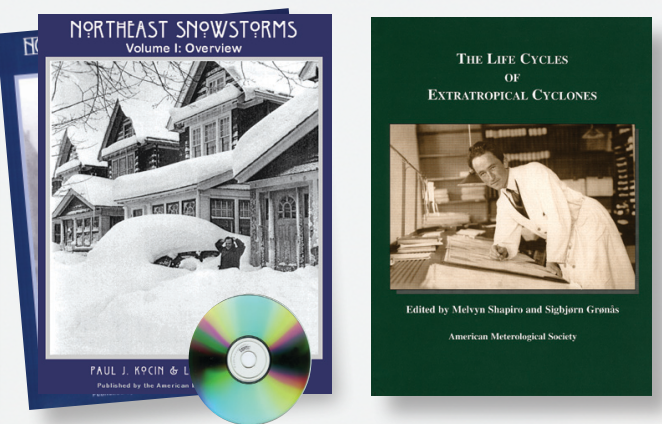

Snowstorms

(Volume I: Overview,

Volume II: The Cases)

PAUL J. KOCIN AND

LOUIS W. UCCELLINI

(c) 2004, TWO HARDCOVER

ISBN 978-1-878220-64-6,

LIST \$100 MEMBER \$80

$M M$ = METEOROLOGICAL MONOGRAPH SERIES

HM = HISTORICAL MONOGRAPH SERIES
The Life Cycles of Extratropical Cyclones

EDITED BY MELVYN A. SHAPIRO AND SIGBJøRN GRøNÅS (C) 1999, HARDCOVER, 359 PAGES,

ISBN 978-1-878220-35-6, AMS CODE: LEC

LIST \$75 MEMBER \$55

Booksellers and wholesale distributors, to place an order please contact The University of Chicago Press: 1-800-621-2736 (US \& Canada) 773-702-7000 (all others) custserv@press.uchicago.edu 


\section{The AMS Weather Book:}

The Ultimate Guide to America's Weather JACK WILLIAMS WITH

FOREWORDS BY RICK ANTHES, PRESIDENT OF NCAR, AND

STEPHANIE ABRAMS OF THE WEATHER CHANNEL

Former USA Today Weather Page editor Jack Williams has written the most comprehensive, up-todate guide to the weather and atmosphere, covering everything from daily weather patterns to air pollution and global warming.

(C)2009, HARDCOVER, 368 PAGES, ISBN 978-0-226-89898-8, AMS CODE: AMSWX LIST \$35 MEMBER \$25
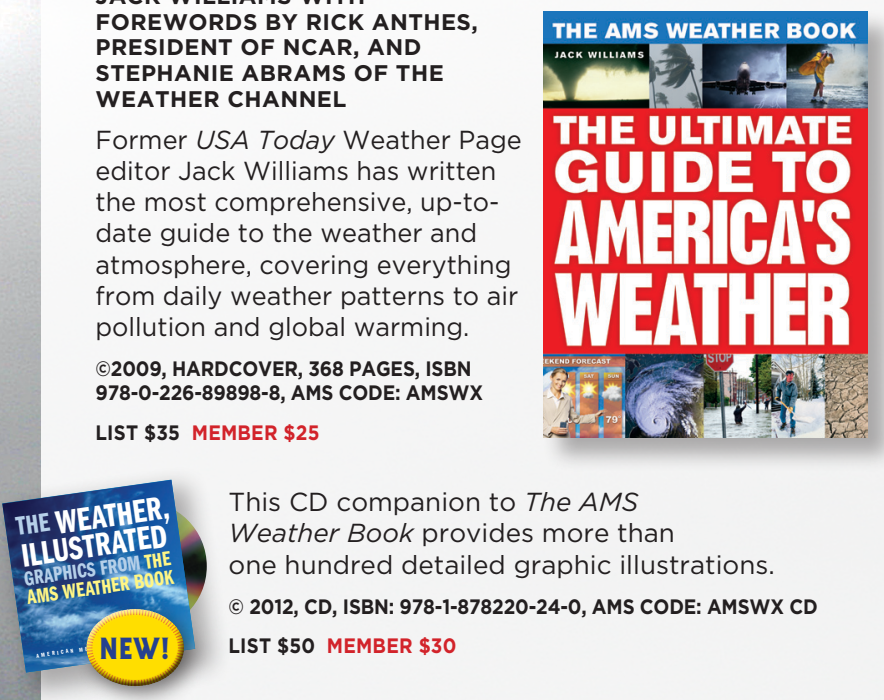

This CD companion to The AMS

Weather Book provides more than

one hundred detailed graphic illustrations.

(c) 2012, CD, ISBN: 978-1-878220-24-0, AMS CODE: AMSWX CD

LIST $\$ 50$ MEMBER $\$ 30$

\section{DIGITAL EDITION NOW AVAILABLE}

\section{Midlatitude Synoptic Meteorology:}

Dynamics, Analysis, and Forecasting

\section{GARY LACKMANN}

This textbook links theoretical concepts to modern technology, facilitating meaningful application of concepts, theories, and techniques using real data. It serves those planning careers in meteorological research and weather prediction and provides a template for the application of modern technology in the classroom. Extratropical cyclones and fronts, topographically trapped flows, weather forecasting, and numerical weather prediction are

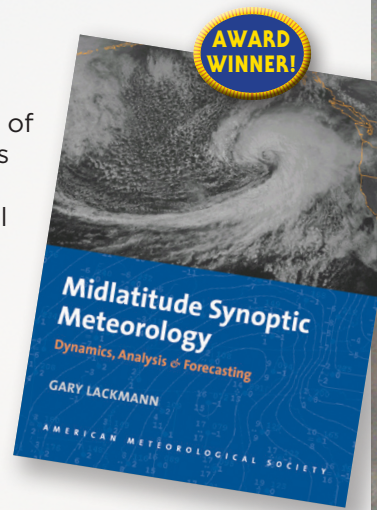
all covered in depth.

(92011, PAPERBACK, 360 PAGES, ISBN 978-1-878220-10-3, AMS CODE: MSM LIST \$100 MEMBER \$75 STUDENT MEMBER \$65

\section{Eloquent Science:}

A Practical Guide to Becoming a Better Writer, Speaker, and Atmospheric Scientist DAVID M. SCHULTZ

The ultimate communications manual for undergraduate and graduate students as well as researchers in the atmospheric sciences and their intersecting disciplines. Every student, teacher, and science department should have a copy.

(c) 2009, PAPERBACK, 440 PAGES, ISBN 978-1-878220-91-2, AMS CODE: ESCI

LIST \$45 MEMBER $\$ 30$

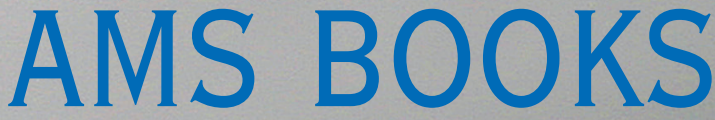

RESEARCH APPLICATIONS HISTORY


H I G H L I G H T S

COMPLETE CATALOG AND DIGITAL EDITIONS ONLINE

WWW.AMETSOC.ORG/AMSBOOKSTORE
Economic and Societal Impacts of Tornadoes

KEVIN M. SIMMONS AND DANIEL SUTTER

Two economists' unique database has enabled a fascinating and game-changing study of tornado impacts and how factors such as storm timing and warning lead time affect impacts; whether Doppler radar and shelters are worth the investment; and more. For meteorologists, social scientists, and emergency managers.

(C2011, PAPERBACK, 296 PAGES, ISBN 978-1-878220-99-8, AMS CODE: ESIT LIST \$3O MEMBER \$22

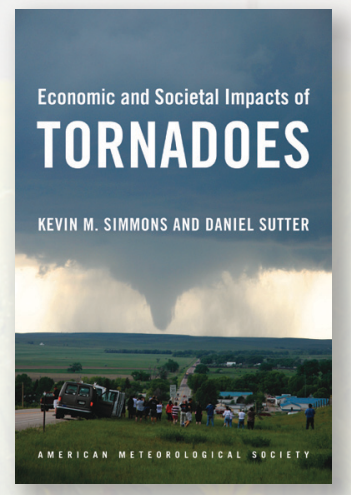


AMS titles now avallable as eBooks at springer.com

\section{AMS BOOKS}

\section{RESEARCH APPLICATIONS HISTORY}

www.ametsoc.org/amsbookstore

\section{6) Springer}

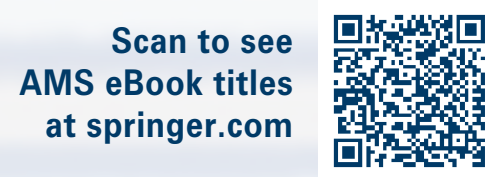

2) Springer



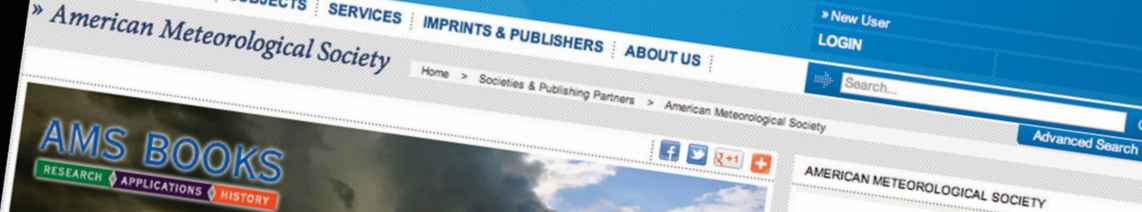

Aneteorological Society eBook

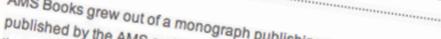

that reaches back five and now encompassing program reiated to the per

Soringer Link as eBooks) odes fformerly out-of-print of metoorological per-reviewed journals

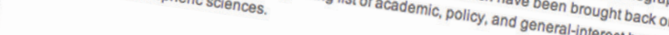

$$
\text { Sort listing by: }
$$

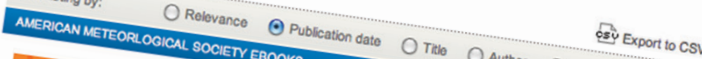

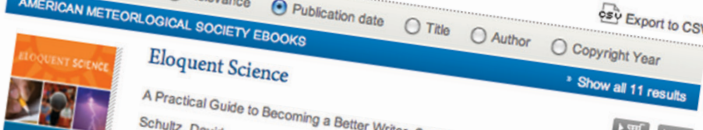

